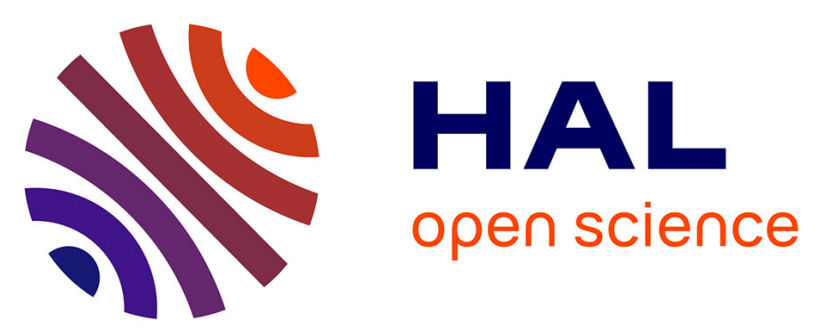

\title{
Vagus nerve stimulation: State of the art of stimulation and recording strategies to address autonomic function neuromodulation
}

\author{
David Guiraud, David Andreu, Stéphane Bonnet, Guy Carrault, Pascal \\ Couderc, Albert Hagège, Christine Henry, Alfredo Hernandez, Nicole Karam, \\ Virginie Le Rolle, et al.
}

\section{To cite this version:}

David Guiraud, David Andreu, Stéphane Bonnet, Guy Carrault, Pascal Couderc, et al.. Vagus nerve stimulation: State of the art of stimulation and recording strategies to address autonomic function neuromodulation. Journal of Neural Engineering, 2016, 13 (4), pp.041002. 10.1088/17412560/13/4/041002 . hal-01372361

HAL Id: hal-01372361 https://hal-univ-rennes1.archives-ouvertes.fr/hal-01372361

Submitted on 19 Jan 2017

HAL is a multi-disciplinary open access archive for the deposit and dissemination of scientific research documents, whether they are published or not. The documents may come from teaching and research institutions in France or abroad, or from public or private research centers.
L'archive ouverte pluridisciplinaire HAL, est destinée au dépôt et à la diffusion de documents scientifiques de niveau recherche, publiés ou non, émanant des établissements d'enseignement et de recherche français ou étrangers, des laboratoires publics ou privés. 


\section{Vagus nerve stimulation: state of the art of stimulation and recording strategies to address autonomic function neuromodulation}

David Guiraud*1,2, David Andreu ${ }^{2,1}$, Stéphane Bonnet ${ }^{3}$, Guy Carrault ${ }^{4,5,14}$, Pascal Couderc $^{6}$, Albert Hagège ${ }^{7,8,9}$, Christine Henry ${ }^{10}$, Alfredo Hernandez ${ }^{4,5}$, Nicole Karam $^{7,8,9}$, Virginie Le Rolle $^{4,5}$, Philippe Mabo ${ }^{4,5,11,14}$, Paweł Maciejasz ${ }^{12}$, Charles-Henri Malbert ${ }^{13}$, Eloi Marijon ${ }^{7,8,9}$, Sandrine Maubert ${ }^{3}$, Chloé Picq ${ }^{12}$, Olivier Rossel ${ }^{1,2}$, Jean-Luc Bonnet ${ }^{* * 10}$

*David Guiraud drafted the manuscript from partner's contributions and supervised the writing of this review, corresponding author

**Jean-Luc Bonnet supervises the consortium "state-of-the-art" search

All other authors contribute to this review and are mentioned in the alphabetical order

All authors declare they do not have any conflict of interest

1 Inria, DEMAR, Montpellier, France

2 University of Montpellier, DEMAR, Montpellier, France

3 University of Grenoble Alpes, CEA, Leti, MINATEC Campus, Grenoble, France

4 University of Rennes 1, LTSI, Rennes, France.

5 INSERM, U1099, Rennes, France

6 3D Plus, Buc, France

7 INSERM UMR 970, Paris Cardiovascular Research Center, Paris, France

8 Paris Descartes University, Sorbonne Paris Cité, Paris, France

9 Assistance Publique - Hôpitaux de Paris, Department of Cardiology, Hôpital Européen Georges Pompidou, Paris, France

10 Sorin Group, New Ventures (a LivaNova company), Clamart, France

11 Centre Hospitalo-Universitaire de Rennes, Rennes, France

12 Axonic, Sophia Antipolis, France

13 Inra, Unité Ani-Scan, Saint-Gilles, France

14 INSERM CiC-IT 1414, Rennes, France

\section{Abstract}

Neural signals along the vagus nerve (VN) drive many somatic and autonomic functions. The clinical interest of $\mathrm{VN}$ stimulation (VNS) is thus potentially huge and has already been demonstrated in epilepsy. However, side effects are often elicited, in addition to the targeted neuromodulation. This review examines the state of the art of VNS applied to two emerging modulations of autonomic function: heart failure and obesity, especially morbid obesity. We report that VNS may benefit from improved stimulation delivery using very advanced technologies. However, most of the results from fundamental animal studies still need to be demonstrated in humans.

Keywords: Vagus nerve stimulation (VNS), Heart failure, Obesity, Gastrointestinal disorders, Selective stimulation, Vagus nerve recordings, Closed-loop control 


\section{Introduction}

The vagus nerve $(\mathrm{VN})$, also called the pneumogastric nerve, is the tenth pair $(\mathrm{X})$ and the longest of the cranial nerves. The VN is a component of the autonomic nervous system (ANS), more specifically of the parasympathetic nervous system, and it innervates various organs, including the heart and digestive system. It also acts on somatic functions, such as those linked to speech. At the cervical level in humans, each trunk (right and left) contains nearly 100,000 afferent and efferent fibers, about 80\% and 20\%, respectively (Foley and DuBois 1937 cited by (George et al., 2000)). The VN is composed of A, B and C fibers (Bailey and Bremer, 1938, cited by (Groves and Brown, 2005, Castoro et al., 2011)), which are characterized by decreasing diameters and velocities and increasing stimulation thresholds (Erlanger and Gasser, 1930 cited by (Duclaux et al., 1976)). Recently, it was shown in humans that the VN comprises around 5\% sympathetic fibers (Seki et al., 2014) and that the mean effective surface area of the right VN is higher than that of the left (Verlinden et al., 2016). Regarding the distribution of VN termination in the heart, the following has been shown: 1) parasympathetic innervation is higher in the atrium than in the ventricle (Kawano et al., 2003); 2) the right atrium is more innervated than the left (Ulphani et al., 2010), and 3) the right ventricle is more innervated than the left (Ulphani et al., 2010). In their seminal publication, Cohn and Lewis (Cohn and Lewis, 1913) proposed that the right VN mostly innervates the sinoatrial node, whereas the left VN predominantly innervates the atrioventricular node, although this hypothesis was not confirmed by preclinical studies (Hamlin and Smith, 1968, Randall and Armour, 1974). Using vagus nerve stimulation (VNS) on both sides, it was demonstrated that right and left VNS have the same effect on heart rate, left ventricular pressure and contractility (Yamakawa et al., 2015).

VNS was first described by Corning (Corning, 1883), who suggested that the seizures of epilepsy could be suppressed by lowering the heart rate. In 1938, Bailey and Bremer demonstrated the direct effect of VNS on central nervous functions (Bailey and Bremer, 1938). MacLean and Pribram then reported in 1949 that VNS induced slow waves over the lateral frontal cortex (cited by (George and Aston-Jones, 2010)), and two years later Dell and Olson determined that proximal stimulation of the $\mathrm{VN}$ evoked responses in the ventroposterior complex and intralaminar regions of the thalamus (Dell and Olson, 1951). In 1952, Zanchetti et al. demonstrated that VNS suppresses the interictal epileptic events in a cat model (Zanchetti et al., 1952). These preliminary studies thus opened the way to using VNS as a therapeutic option in the treatment of epilepsy. In 1985, Zabara described for the first time the effect of VNS on seizure control in a canine model (Zabara, 1985). This study has since been confirmed and complemented by the findings of several authors (Lockard et al., 1990, Woodbury and Woodbury, 1990, McLachlan, 1993).

Given this history, we can easily understand the interest of stimulating the VN using implantable devices to modulate essential functions. Yet, although stimulation of peripheral nerves is now a well-known concept, the richness and complexity of the information transmitted along the VN raises serious challenges that have thus far hampered the more rapid and widespread use of VNS. Intensive research has nevertheless been ongoing for the same reasons. 
VNS was successfully used to treat epilepsy with an implantable neurostimulator, and this is by far its most extensive application. The first study in humans was published in 1990 (Penry and Dean, 1990) in a small series of patients. The first international study with a larger population was published in 1994 (Ben-Menachem et al., 1994), and it confirmed the effectiveness of VNS in the epilepsy treatment. An earlier review \{Binnie, 2000) reported the clear benefits of VNS, with a significant reduction in seizure frequency. However, the percentage of patients for which VNS is very efficient (number of seizures reduced by $>50 \%$ ) remains under one third and the placebo effect was not clearly assessed in the above-mentioned studies. Side effects such as pain, voice changes and coughing have been reported as limitations to the possible efficacy of VNS and therefore, to avoid these adverse effects, stimulation intensity cannot be increased up to a level for which a positive effect is obtained. In a long-term study of patients followed for more than ten years (Elliott et al., 2011), the authors observed significant seizure reduction, with an increasing effect over time: $>75 \%$ at 10 years).

The present review will focus on two promising therapeutic application of VNS: heart failure and obesity; nevertheless, VNS has been studied in many other clinical applications:

- depression (Rush et al., 2000, Goodnick et al., 2001, Sackeim et al., 2001, Lomarev et al., 2002, Mu et al., 2004, Rush et al., 2005a, Rush et al., 2005b, George et al., 2005, Nahas et al., 2005, Bodenlos et al., 2007, Labiner and Ahern, 2007, Daban et al., 2008, Milby et al., 2008, Schlaepfer et al., 2008, Bajbouj et al., 2010, Sperling et al., 2010, Aaronson et al., 2013, Conway et al., 2013, Feldman et al., 2013, Landau et al., 2015, Grimonprez et al., 2015);

- inflammation and autoimmune diseases (Borovikova et al., 2000, van Westerloo et al., 2006, Barone et al., 2007, Zitnik, 2011, Kox et al., 2012, Mihaylova et al., 2012, Bonaz et al., 2013, Levine et al., 2014, Yamakawa et al., 2013, Didier et al., 2014, Pellissier et al., 2014, Li et al., 2015, Bonaz et al., 2016);

- cognition and brain injury (Masada et al., 1996, Clark et al., 1999, George et al., 2000, Furmaga et al., 2012, Lopez et al., 2012, Mihaylova et al., 2012, Sun et al., 2012, Khodaparast et al., 2013, Yamakawa et al., 2013, Vonck et al., 2014, Hays et al., 2014, Ay et al., 2014, Cai et al., 2014, Jiang et al., 2014, Pena et al., 2014, Chunchai et al., 2015, Neren et al., 2015, Dawson et al., 2016);

- arrhythmias (Kolman et al., 1975, Zuanetti et al., 1987, Vanoli et al., 1991, Murakawa et al., 2003, Zheng et al., 2005, Brack et al., 2007, Ng et al., 2007, Li et al., 2009, Zhang et al., 2009a, Shen et al., 2011, Brack et al., 2011, Yu et al., 2011, Shinlapawittayatorn et al., 2013, Stavrakis et al., 2013, Huang et al., 2014, Annoni et al., 2015, Huang et al., 2015, Stavrakis et al., 2015, Zhang et al., 2015a, Zhang et al., 2016);

- ischemia and myocardial infarction (Kent et al., 1973, Myers et al., 1974, Sneddon et al., 1993, Zamotrinsky et al., 2001, Li et al., 2005, Katare and Sato, 2007, Del Rio et al., 2008, Katare et al., 2010, Uemura et al., 2010, Calvillo et al., 2011, Wu and Lu, 2011, Kong et al., 2012, Shinlapawittayatorn et al., 2013, Beaumont et al., 2015, Chen et al., 2015, Uitterdijk et al., 2015 , Zhang et al., 2015b);

- anxiety (Rush et al., 2005a, Chavel et al., 2003, Childs et al., 2015);

- pain (Kirchner et al., 2000, Kirchner et al., 2006, De Couck et al., 2014 , Chakravarthy et al., 2015);

- hypertension (Gierthmuehlen and Plachta, 2015, Annoni et al., 2015);

- migraines and headache (Hord et al., 2003). 
The remainder of the paper will nevertheless concentrate on cardiac and digestive clinical applications. The paper first presents the known VNS mechanisms on the targeted pathologies. The state of the art of the technologies involved in VNS and the clinical results are then presented, followed by a review of the recent research that suggests new stimulation paradigms.

\section{Anatomy and physiology of the autonomic functions}

\subsection{Cardiac function}

In normal cardiac function, the adapted amount of blood is continuously carrying to the entire organism, according to organ needs. In response to physical and physiological modifications, the heart adapts its strength, power and speed, as does the peripheral vascular system, which can contract and expand. Thereby, the heart controls its rate and contractility. Heart failure (HF) can be defined in different ways depending on whether one takes the pathophysiological or clinical perspective. Pathophysiologically, the structure or function of the heart is abnormal, leading to the inability of the cardiac pump to ensure sufficient blood flow to meet the body's metabolic needs under normal conditions. Clinically, HF is a syndrome combining functional (asthenia, dyspnea) and physical (crackles, lower limb edema, jugular turgor, hepatojugular reflux) signs. The European Society of Cardiology defines it thusly: "Heart failure as a clinical syndrome in which patients have typical symptoms and signs resulting from an abnormality of cardiac structure and function" (McMurray et al., 2012).

In the general adult population in Western countries, HF prevalence is estimated to be between 1 and 2\% (Parameshwar et al., 1992, McDonagh et al., 1997, Davies et al., 2001, Murphy et al., 2004). In the aged population (Tiller et al., 2013), the overall prevalence is $7.7 \%$ for men and 9.0\% for women, with the prevalence (Eriksson et al., 1989, Kupari et al., 1997, Mosterd et al., 1999, Morgan et al., 1999, Vaes et al., 2012) and incidence increasing significantly with age (Cowie et al., 1999, Murphy et al., 2004).

It is well known that the heart is under the control of both sympathetic and parasympathetic nervous systems (Levy, 1971), leading to the concept of "autonomic balance." Stimulation of the sympathetic nervous system increases heart rate, blood pressure and myocardial inotropism, while stimulation of the parasympathetic nervous system reduces heart rate, blood pressure, and contractility. Both systems act to regulate heart rate, blood pressure, cardiac structure and function, and the electrical stability of the myocardium. Autonomic imbalance, characterized by decreased vagal (parasympathetic) activity and increased sympathetic activity, correlates with cardiovascular diseases such as HF, arrhythmias, ischemia/reperfusion injury and hypertension.

In HF, decreased cardiac output leads to compensatory mechanisms, particularly activation of the renin-angiotensin-aldosterone system (RAAS) (Bristow, 1984) and the sympathetic nervous system, through afferent stimuli from the baroreceptors to the central nervous system cardioregulatory centers (Parati and Esler, 2012). These compensatory mechanisms initially help maintain cardiac output but are detrimental over the long term through reduced cardiac sympathetic neuronal density and responsiveness, increased vasoconstrictor tone, and further activation of the RAAS and the endothelin 1 and vasopressin systems, which may be responsible 
for peripheral organ dysfunction and damage (Floras, 2009). Increased sympathetic activity, besides being proarrhythmic, is also associated with nitric oxide deregulation, increased inflammation with excess cytokine release and adverse ventricular remodeling (Ogawa et al., 2007, Li and Olshansky, 2011). Experimental (Billman et al., 1982, Vanoli et al., 1991) and clinical (La Rovere et al., 1998) works have also shown that (i) depressed vagal reflexes measured via baroreflex sensitivity (BRS) and heart rate variability (HRV) - are strongly associated with susceptibility to ventricular arrhythmias in the early postinfarction period and (ii) depressed BRS in patients with HF with reduced left ventricular ejection fraction (LVEF) identifies those at high risk for cardiac and arrhythmic mortality (Billman et al., 1982, La Rovere et al., 1998). Moreover, sympathetic nerve hyperactivity was shown to be related to impaired cardiac performance in patients with HF (Ferguson et al., 1990). In a large clinical study, Mortara et al. demonstrated that in HF patients with reduced LVEF, the BRS is reduced in parallel with the clinical and hemodynamic status (Mortara et al., 1997). These findings have led to the hypothesis that VNS may offer an opportunity to regulate the "sympatovagal balance".

The aims of HF treatment are to control symptoms and improve functional capacity, reduce hospitalizations and decrease mortality. The therapeutic strategies were established by the European Society of Cardiology (McMurray et al., 2012), and they consist of single or combined pharmacological approaches: diuretics (Marvin, 1927), beta-blockers and ACE inhibitors (angiotensin-converting-enzyme) (Ho et al., 2014), Ivabradine to reduce heart rate (Fox et al., 2008, Swedberg et al., 2010) or a combination of molecules (McMurray et al., 2014).

In certain cases, defined by the European society of cardiology (McMurray et al., 2012), the pharmaceutical treatment can be completed by the implantation of a medical device, such as an implantable cardioverter/defibrillator (CONSENSUS investigators, 1987, AVID investigators, 1997, Kadish et al., 2004) or a cardiac resynchronization device (Cazeau et al., 2001, Bristow et al., 2004, Moss et al., 2009, Linde et al., 2010, Tang et al., 2010, Bogale et al., 2012, McMurray et al., 2012, Brignole et al., 2013).

For patients with end-stage HF, the conventional therapeutic solutions are limited to cardiac transplantation or a left ventricular assist device (McMurray et al., 2012). The implantable artificial heart is a new emergent opportunity (Copeland et al., 2004, Tarzia et al., 2014, Latremouille et al., 2015).

\subsection{Weight control}

The central nervous system (CNS) controls eating behavior and energy regulation. New, welltolerated and effective therapies are needed to help curb the growing obesity epidemic. Ongoing research and a deepening understanding of the relationship between the gastrointestinal tract and the brain in the control of eating behavior, as well as electrical stimulation as a therapy, have helped open new "windows" for developing long-lasting and safe obesity treatment. Indeed, a new approach to obesity treatment that is currently being tested focuses on its effect on the interaction between the CNS and the gastrointestinal tract. This interaction is mainly handled by the VN (Roslin and Kurian, 2001), which has a role in linking the brain and the gut for bidirectional communication. It has been shown that afferent neurons of the VN propagate information to the brain on the control of food intake and thus feed homeostasis (Bray, 2000, Ziomber et al., 2009). In non-obese individuals, chemo- and mechanosensory vagal receptors 
signal the immediate availability of food to the brain. This signaling is altered in the obese as a consequence of the reduced sensitivity of small intestinal afferents. Since chronic VNS has the potential to restore this missing or altered signaling, it might be an effective treatment for obesity. Using the pig as a preclinical model, Val-Laillet used juxta-abdominal bilateral VNS in the longest longitudinal study performed to date (Val-Laillet et al., 2010a). They showed that VNS decreased weight gain, food consumption and sweet craving in adult obese minipigs. However, the long delay observed between the onset of stimulation and the appearance of beneficial effects exemplifies our current inability to fully understand the brain mechanisms involved by VNS.

To further understand the intricacies of VNS effects on food intake, brain functional imaging in a large animal model cab has helped to identify the brain networks affected by VNS. Early studies on brain activation after juxta-abdominal bilateral VNS performed in growing pigs using singlephoton gamma scintigraphy evaluated the VNS effect on non-pathologic brain (Biraben et al., 2005, Biraben et al., 2008). They showed the activation of two networks: (i) the first is associated with the olfactory bulb and primary olfactory projections areas, and (ii) the second involves areas already demonstrated as essential to integrate gastroduodenal mechanosensory information (hippocampus, pallidum) so as to give hedonic valance to them. More recently, our group used PET FDG imaging to evaluate the potential changes in glucose metabolism induced in the brain by VNS. Unlike behavioral effects that take several weeks to be identified, modifications in glucose metabolism, which reflects brain activity, were present one week after the onset of VNS therapy. The following brain areas presented significant differences compared with the effects of sham stimulation: cingular cortex, putamen, caudate nucleus and the substancia nigra/tegmental ventral area. Interestingly, these areas are part of the main mesolimbic dopaminergic reward network (Malbert, 2013). The massive activation of the reward network at an early stage of chronic stimulation suggests that brain imaging might be a tool to optimize the VNS parameters and/or that part of the effect on body weight might relate to the involvement of the reward network.

\section{Current approaches}

\subsection{Existing implantable devices for $\mathrm{HF}$}

In an experimental study, Myers et al. showed that VNS reduces the incidence of spontaneous ventricular fibrillation (Myers et al., 1974). These findings were confirmed by Vanoli et al. (Vanoli et al., 1991) in acute ischemic episodes in dogs. More recently, VNS has been evaluated in animal models with HF with reduced LVEF (Li et al., 2004, Sunagawa, 2005, Sabbah et al., 2007, Zhang et al., 2009b). VNS devices have also been implanted and evaluated in humans (Table 1). In a small series, the first human experiment on VNS to treat HF (Schwartz et al., 2008) showed that NYHA class and quality of life (QOL) were significantly improved. Table 1 summarizes the preliminary data demonstrating the safety of direct VNS in HF patients with low LVEF. These data suggest significant improvement in the subjective and objective endpoints of $\mathrm{HF}$, although the results need to be confirmed in larger multicenter randomized studies focused on morbidity and mortality data. The benefits may be mediated by slower heart rate, blunting of the sympathetic activity, inhibition or down-regulation of the RAAS, and enhanced signaling pathways, which facilitate restoration of the BRS, suppression of the proinflammatory cytokines, 
and suppression of gap junction remodeling (Sabbah et al., 2011). However, the authors of the NECTAR-HF study, for example, hypothesized that the placebo effect is partly responsible for these results, as blinding has not yet been reached. Another explanation may be related to the titration process, which is limited by patients' side effects. The mean current applied in the study was considerably less than in a previous study (4.1 $\pm 1.2 \mathrm{~mA})$ (Kuck et al., 2014). This last study in particular confirms that managing the side effects induced by VNS at the cervical level is a key point for the future development of this therapy. Suggested major contributing mechanisms are listed in Table 2.

\begin{tabular}{|c|c|c|}
\hline Study & Stimulation paradigm / study design & Main results \\
\hline $\begin{array}{l}\text { CardioFit system BioControl Medical Ltd } \\
\text { (Yehudi, Israel) } \\
\text { Preliminary study } \\
\text { (Schwartz et al., 2008) } \\
\text { (De Ferrari et al., 2011) } \\
\text { INOVATE-HF study } \\
\text { (Gold et al., 2016) }\end{array}$ & $\begin{array}{l}\text { Asymmetric bipolar multi-contact cuff } \\
\text { electrode designed to preferentially activate } \\
\text { the efferent B fibers in the right cervical VN. } \\
\text { Synchronous VNS on cardiac events, one or } \\
\text { two pulses are delivered by cardiac cycle. } \\
\text { Right ventricular sensing electrode to prevent } \\
\text { excessive bradycardia from VNS (Anholt et } \\
\text { al., } 2011 \text { ). } \\
\text { A preliminary study involved } 8 \text { patients in a } \\
\text { first step and } 32 \text { patients in a second step. It } \\
\text { was a non controlled and non randomized } \\
\text { study. } \\
\text { The INOVATE-HF was a randomized and } \\
\text { controlled study. It involved } 707 \text { patients in a } \\
3: 2 \text { ration (implanted device vs. standard } \\
\text { medical therapy). The mean current was } 3.9 \pm \\
1.0 \text { mA. No data were published on the } \\
\text { number of pulses per cardiac cycle. }\end{array}$ & $\begin{array}{l}\text { In preliminary study, HF with reduced LVEF } \\
\text { showed that hemodynamic performances } \\
\text { were significantly improved by VNS. Results } \\
\text { were confirmed by an open-label multi-centre } \\
\text { pilot study in } 32 \text { patients with NYHA class } \\
\text { II-IV and LVEF<35\%, which demonstrated } \\
\text { the positive impact of VNS on structural and } \\
\text { functional endpoints. A substantial proportion } \\
\text { of patients improved their NYHA class and 6- } \\
\text { min walk test, with an improvement in LVEF } \\
\text { and QoL. } \\
\text { INOVATE-HF failed to demonstrate a benefit } \\
\text { on cardiac parameters. }\end{array}$ \\
\hline $\begin{array}{l}\text { Boston Scientific Corporation (Marlborough, } \\
\text { MA, USA) } \\
\text { NECTAR-HF } \\
\text { (Zannad et al., 2015) }\end{array}$ & $\begin{array}{l}\text { The electrode is a bipolar helical system. } \\
\text { The VNS was delivered asynchronously at } 20 \\
\text { Hz. } \\
2: 1 \text { randomized sham-controlled trial in } 96 \\
\text { NYHA II/II patients with LVEF }<35 \% \text {. } \\
\text { Mean current applied } 1.4 \pm 0.8 \mathrm{~mA} \text {. }\end{array}$ & $\begin{array}{l}\text { The study failed to demonstrate at } 6 \text { months a } \\
\text { favorable effect of direct right VNS (versus } \\
\text { VNS OFF) on left ventricular end systolic } \\
\text { diameter (LVESD) (primary endpoint). } \\
\text { No benefit on left ventricular end diastolic } \\
\text { dimension and volume, left ventricular end } \\
\text { systolic volume and ejection fraction, peak } \\
\mathrm{VO}_{2} \text { and NT-proBNP. } \\
\text { An improvement demonstrated in subjective } \\
\text { parameters such as NYHA class and QoL. }\end{array}$ \\
\hline $\begin{array}{l}\text { Cyberonics (Houston, USA) } \\
\text { ANTHEM-HF } \\
\text { (Premchand et al., 2014) } \\
\text { ENCORE } \\
\text { (Premchand et al., 2015) }\end{array}$ & $\begin{array}{l}\text { The electrode is a bipolar helical system. } \\
\text { The VNS was delivered asynchronously at } 10 \\
\text { Hz. } \\
\text { Comparison of right versus left cervical VNS } \\
60 \text { patients, without control group. }\end{array}$ & $\begin{array}{l}\text { No difference between these } 2 \text { configurations. } \\
\text { Improvement of LVEF at } 6 \text { months compared } \\
\text { to baseline. } \\
\text { In the ENCORE study, a subgroup of } 49 \\
\text { patients from ANTHEM-HF, it has been } \\
\text { shown that the improvement in cardiac } \\
\text { function and HF symptoms were maintained } \\
\text { at } 12 \text { months }\end{array}$ \\
\hline
\end{tabular}

Table 1: summary of clinical studies. QoL: quality of life; LEVF: left ventricular ejection fraction; NYHA class: New-York Heart Association classification

\begin{tabular}{|l|l|l|}
\hline Effect & Publication & Main results \\
\hline Antiarrhythmic effects at the ventricular level & $\begin{array}{l}\text { (Prystowsky et al., 1981) } \\
\text { (Litovsky and Antzelevitch, 1990) } \\
\text { (Vanoli et al., 1991) } \\
\text { (Li et al., 2004) } \\
\text { (Zheng et al., 2005) } \\
\text { (Ng et al., 2007) } \\
\text { (Kuck et al., 2014) }\end{array}$ & $\begin{array}{l}\text { VNS increases the ventricular refractory } \\
\text { period in humans. It leads to a prolongation of } \\
\text { the epicardial action potential duration and } \\
\text { decreases vulnerability to ventricular } \\
\text { fibrillation. Its antifibrillatory effects was } \\
\text { demonstrated in post-infarction animal } \\
\text { models; VNS decreases sudden cardiac death } \\
\text { in dogs with a healed myocardial infarction. } \\
\text { In a rat model of myocardial infarction- } \\
\text { induced HF, VNS significantly reduced } \\
\text { arrhythmias and increased long-term survival. } \\
\text { It prevents the loss of connexin-43 induced by }\end{array}$ \\
\hline
\end{tabular}




\begin{tabular}{|l|l|l|}
\hline & & ischemia, improving electrical stability. \\
\hline Rate slowing effects & (Bohm et al., 2010) & $\begin{array}{l}\text { VNS exerts deep negative chronotropic and } \\
\text { dromotropic effects. A reduction of heart rate } \\
\text { might contribute to beneficial therapeutic } \\
\text { effects in HF. }\end{array}$ \\
\hline Antifibrotic effects & (Zhang et al., 2009b) & $\begin{array}{l}\text { It shows that VNS decreases ventricular } \\
\text { replacement fibrosis and blunts the } \\
\text { development of HF-associated cellular } \\
\text { hypertrophy of remaining myocytes in a } \\
\text { coronary microembolization-induced HF. }\end{array}$ \\
\hline Anti-inflammatory effects & $\begin{array}{l}\text { VNS anti-inflammatory effects was shown to } \\
\text { blunt HF-associated increases of TNF- } \alpha, \text { IL-6 } \\
\text { and CRP in two animal models of HF. }\end{array}$ \\
\hline Reverse remodeling & (Zhang et al., 2009b) & $\begin{array}{l}\text { VNS decreases LV end-systolic and end- } \\
\text { diastolic diameters, improves LVEF reduces } \\
\text { NT-proBNP levels in a dog HF model and } \\
\text { biventricular weight in a rat HF model. }\end{array}$ \\
\hline Antiarrhythmic effects at the atrial level & $\begin{array}{l}\text { (Li et al., 2004) } \\
\text { (Zhang et al., 2009b) }\end{array}$ & $\begin{array}{l}\text { Autonomic nerve activity may contribute to } \\
\text { atrial fibrillation (AF) initiation or control. } \\
\text { While VNS might be inefficient at high } \\
\text { intensities, low-level VNS below the needed } \\
\text { threshold to reduce heart rate, is effective in } \\
\text { suppressing AF induction in anesthetized } \\
\text { dogs. }\end{array}$ \\
\hline
\end{tabular}

Table 2: VNS effects when applied to HF.

In parallel to VNS through implantable devices, transcutaneous VNS (tVNS) has been proposed as an alternative approach (Ellrich, 2011, Kreuzer et al., 2012, Kampusch et al., 2013). Few studies have been conducted for the treatment of cardiac diseases by tVNS (Zamotrinsky et al., 2001, Yu et al., 2013, Clancy et al., 2014, Wang et al., 2014a, Wang et al., 2014b, Ay et al., 2015, Stavrakis et al., 2015, Wang et al., 2015a, Wang et al., 2015c, Wang et al., 2015b, Zhou et al., 2016).

\subsection{Existing implantable devices for weight control}

Nowadays treatment options for obesity remain limited. These include diets, exercise programs, drugs, and bariatric surgery. Surgery is a frequent option because of its short- and long-term efficiency but it is limited to patients meeting the criterion of a body mass index (BMI) greater than $40 \mathrm{~kg} / \mathrm{m}^{2}$ or greater than to $35 \mathrm{~kg} / \mathrm{m}^{2}$ with severe comorbidities. Moreover, bariatric surgery carries the risk of serious side effects such as long-term nutritional deficiencies and surgical complications. As these techniques focus on the gastrointestinal tract and caloric reduction, VNS may be a valuable alternative.

Vagotomy has historically been a therapy for ulcer. Studies on patients with vagotomy have shown short-term weight loss, with some patients presenting prolonged loss of weight and appetite (Gortz et al., 1990). Based on these observations and trials of bilateral vagotomy as a treatment for obesity (Camilleri et al., 2008, Kral et al., 2009) - even though the results were mitigated - Enteromedics developed a device to induce weight loss. This device induces the blockade of the VN and the technique is called VBLOC therapy. The device is laparoscopically implanted. The stimulator is transcutaneously rechargeable and placed subcutaneously on the thoracic sidewall. Enteromedics received FDA approval in 2014. Other companies (e.g., abiliti ${ }^{\circledR}$ 
device, IntraPace Inc., San Jose, USA) are working on gastric electrical stimulation (GES) to induce the pacing of gastric contractions. GES causes early satiety and a sensation of fullness, mimicking the physiological signals the stomach sends to the brain when digesting food (Ladabaum et al., 1998, Chen, 2004). GES treatment for obesity began 20 years ago (Greenway and Zheng, 2007, Cha et al., 2014), and two studies (Table 3) have been conducted but without control groups. However, the authors compared the percentage of excess weight loss they observed with abiliti ${ }^{\circledR}(49.3 \%)$ to the gastric banding weight-loss efficacy range (35\%). The presence of the intragastric sensor seemed to be well tolerated in both studies, but its invasiveness should be studied for longer periods to evaluate its effect on the stomach mucosa, particularly regarding infection or inflammation. One advantage of the technique is that the surgery required for the implantation is less invasive than bariatric surgery and leads to fewer complications. An earlier GES system (Transcend, Transneuronix, Medtronic in 2005) was placed by laparoscopy, 6 $\mathrm{cm}$ from the pylorus and $3 \mathrm{~cm}$ from the edge of the lesser gastric curvature, below the "goose foot." The study (Table 3) concluded that the effect was similar to that of other noninvasive techniques but that more research was needed to ensure that weight loss would be durable and to compare the efficacy against a control group. A clinical study is currently ongoing with the implantable GES Exilis (Medtronic), but data are not yet available (clinicaltrials.gov \#NCT01823705) (Abell et al., 2015).

The Tantalus Diamond (Metacure, Kfar-Saba, Israel) stimulates the gastric antrum when food enters the stomach (Mizrahi et al., 2012). Weight loss and glycemic control were shown in two studies (Table 3); however, in Sanmiguel et al, the weight loss was not correlated with the improved glucose control (Sanmiguel et al., 2009). Based on these analyses, it appears that the system induces moderate weight loss in diabetic patients, although the device has an effect on glucose metabolism. The Tantalus Diamond device obtained the CE mark in January 2007.

\begin{tabular}{|c|c|c|}
\hline Study & Stimulation paradigm & Main results \\
\hline $\begin{array}{l}\text { Enteromedics system } \\
\text { EMPOWER } \\
\text { (Sarr et al., 2012) }\end{array}$ & $\begin{array}{l}2 \text { electrodes placed on the anterior and } \\
\text { posterior VN at the gastroesophageal } \\
\text { junction. } \\
\text { Biphasic pulses, } 5 \mathrm{kHz}, 3 \text { to } 8 \mathrm{~mA}, 5 \text { minutes } \\
\text { ON, } 5 \text { minutes OFF, delivering stimuli for } 9 \\
\text { to } 16 \text { hours per day. } \\
\text { VBLOC therapy (blockade of } \mathrm{VN} \text { ). }\end{array}$ & $\begin{array}{l}\text { Weight loss but no significant effect of } \\
\text { VBLOC therapy between the sham group and } \\
\text { "blocked" group maybe biased by device } \\
\text { checkups that needs activation. } \\
\text { A subgroup analysis revealed a strong } \\
\text { correlation between the improved excess } \\
\text { weight loss and the hours of use of the } \\
\text { stimulator. An important excess weight loss } \\
\text { was obtained compared to controls with a use } \\
\text { superior to } 12 \text { hours per day. }\end{array}$ \\
\hline $\begin{array}{l}\text { Enteromedics system } \\
\text { Clinical study } 1 \\
\text { (Ikramuddin et al., 2014) } \\
\text { Clinical study } 2 \\
\text { (Shikora et al., 2013) }\end{array}$ & $\begin{array}{l}\text { Same as above but for sham } \mathrm{n} \text { o stimulation } \\
\text { occurred. } \\
239 \text { participants with a BMI range of } 35 \text { to } 45 \\
\mathrm{~kg} / \mathrm{m}^{2} \text { for study } 1 \\
\text { 12-month clinical study } 2 \text { on obese patients } \\
\text { with type } 2 \text { diabetes mellitus }\end{array}$ & $\begin{array}{l}\text { Demonstration of efficacy of the therapy and } \\
\text { safety of the device } \\
\text { Weight loss was statistically more important } \\
\text { in the vagal block group than in the sham } \\
\text { group. } \\
\text { At } 12 \text { months, the "VN blocked" group } \\
\text { presented a } 24.4 \% \text { of excess weight loss vs. } \\
15.9 \% \text { in the sham group. } \\
\text { The co-primary objective not reached: mean } \\
\text { percentage weight loss superior by a } 10 \text {-point } \\
\text { target to the sham group with at least } 55 \% \text { of } \\
\text { patients in the "VN blocked" group achieving } \\
20 \% \text { loss and } 45 \% \text { achieving a } 25 \% \text { loss. } \\
\text { Adverse events rate was } 3.7 \% \text {. The primary } \\
\text { safety objective was reached: rate of serious } \\
\text { adverse events inferior to } 15 \% \text {. } \\
\text { The most common adverse event for both } \\
\text { groups was pain at the neuroregulator site. } \\
\text { Adverse events recorded as mild or moderate } \\
\text { for the "VN blocked" group only were: } \\
\text { hertburn and dyspepsia, pain, dysphagia, }\end{array}$ \\
\hline
\end{tabular}




\begin{tabular}{|c|c|c|}
\hline & & $\begin{array}{l}\text { nausea. Those adverse events were less severe } \\
\text { than those found with bariatric surgery. } \\
\text { The study } 2 \text { revealed VBLOC therapy as safe } \\
\text { and efficient. } \\
\text { Patients had a significant and sustained } \\
\text { excess weight loss of } 25 \% \text {. } \\
\text { Rapid and significant effect on glycemic } \\
\text { control and blood pressure. }\end{array}$ \\
\hline $\begin{array}{l}\text { abiliti® device, IntraPace } \\
\text { (Ladabaum et al., 1998, Chen, 2004) } \\
\text { (Greenway and Zheng, 2007, Cha et al., } \\
\text { 2014) } \\
\text { Clinical studies } \\
\text { (Horbach et al., 2015, Miras et al., 2015) }\end{array}$ & $\begin{array}{l}\text { GES } \\
2 \text { electrodes placed on the serosa of the } \\
\text { proximal stomach. } \\
\text { Food sensor, transgastric electrode, is placed } \\
\text { through the stomach gastric wall: the } \\
\text { stimulation is meal-activated } \\
\text { The stimulation electrode is implanted on the } \\
\text { anterior wall of the stomach. } \\
\text { An accelerometer records patient's activity. } \\
\text { Stimulation parameters: } 4 \text { to } 30 \mathrm{~mA}, 100- \\
2000 \mu \text { s pulse duration, } 40-120 \mathrm{~Hz} \text {. } \\
34 \text { obese patients. } \\
\text { The follow-up was carried out at } 12 \text { months } \\
\text { and } 27 \text { months. }\end{array}$ & $\begin{array}{l}\text { Mean excess weight loss of } 28.7 \% \text { at } 12 \\
\text { months and of } 27.5 \% \text { at } 27 \text { months. } \\
\text { Stable effect of weight loss overtime. } \\
\text { Analysis of questionnaires reveals that } \\
\text { patients improve their eating behavior as well } \\
\text { as their QOL. } \\
\text { Feedback on exercise and food intake } \\
\text { recorded by the intragastric sensor is } \\
\text { described as important to induce those } \\
\text { changes in behaviors. } \\
\text { Patients underwent gastro-endoscopic } \\
\text { examinations to ensure that there was no } \\
\text { problem with the intragastric probe. }\end{array}$ \\
\hline $\begin{array}{l}\text { abiliti }{ }^{\circledR} \text { device, IntraPace } \\
\text { (Miras et al., 2015) }\end{array}$ & $\begin{array}{l}\text { Same as above } \\
27 \text { obese patients with BMI } 30 \text { to } 46 \mathrm{~kg} / \mathrm{m}^{2}\end{array}$ & $\begin{array}{l}49.3 \% \text { excess weight loss at } 12 \text { months with } \\
\text { no significant difference between age and } \\
\text { gender. } \\
\text { Using a subgroup analysis they showed that } \\
\text { stimulation was more effective for patients } \\
\text { with a lower BMI }\left(30-40 \mathrm{~kg} / \mathrm{m}^{2}\right) \text { than for } \\
\text { those with a higher BMI. } \\
\text { No adverse effects, but some patients felt } \\
\text { mild stomach cramping during stimulation. } \\
\text { These patients underwent a reprogramming of } \\
\text { their stimulation parameters that led to the } \\
\text { disappearance of those symptoms. }\end{array}$ \\
\hline $\begin{array}{l}\text { Transcend, Transneuronix } \quad \text { acquired } \\
\text { Medtronic in } 2005 \\
\text { (Favretti et al., 2004) }\end{array}$ & $\begin{array}{l}\text { GES } \\
20 \text { morbid obese patients } \\
1 \text { electrode placed in the gastric muscular } \\
\text { wall of the stomach. } \\
\text { Stimulation parameters used were the } \\
\text { following: } 10 \mathrm{~mA}, 208 \mu \text { s for pulse width, } 40 \\
\mathrm{~Hz}, 2 \text { seconds ON and } 3 \text { seconds OFF }\end{array}$ & $\begin{array}{l}\text { effect on weight loss: after } 1 \text { month a } 10.6 \% \\
\text { excess weight loss was observed reaching } \\
23.8 \% \text { at } 10 \text { months. } \\
\text { No serious complications were recorded. }\end{array}$ \\
\hline $\begin{array}{l}\text { Tantalus Diamond (Metacure, Kfar-Saba, } \\
\text { Israel) } \\
\text { (Mizrahi et al., 2012) } \\
\text { (Sanmiguel et al., 2009) } \\
\text { Clinical studies } \\
\text { (Bohdjalian et al., 2006, Lebovitz et al., 2013) }\end{array}$ & $\begin{array}{l}\text { Electrical stimulation of the gastric antrum } \\
\text { when food is ingested in the stomach. } \\
3 \text { sets of bipolar electrodes that are placed in } \\
\text { the gastric wall: one used as a sensor in the } \\
\text { gastric fundus, two used for stimulation meal- } \\
\text { activated. } \\
\text { Stimulation parameters: biphasic symmetric, } \\
\text { therapy delivered for approximately } 75 \\
\text { minutes (depending on patients) starting at } \\
\text { the onset of a meal, } 0.5 \text { to } 15 \mathrm{~mA} \text { (depending } \\
\text { on the patient's feeling), } 6 \mathrm{~ms} \mathrm{phase} \mathrm{duration,} \\
1,200 \mathrm{~ms} \text { for pulse duration, } 83 \mathrm{~Hz} \\
12 \text { obese subjects for the first study. }\end{array}$ & $\begin{array}{l}\text { Bohdjalian et al. shows an excess weight loss } \\
\text { of } 30.5 \% \text { at } 52 \text { weeks. } \\
\text { Both showed an improvement of glycemic } \\
\text { control and a modest weight loss in patients } \\
\text { with Type } 2 \text { diabetes at } 12 \text { months for the } \\
\text { second study. }\end{array}$ \\
\hline
\end{tabular}

Table 3: studies about weight loss.

\section{Recent scientific and technological breakthroughs}

The main limitations of VNS for either obesity or HF are its therapeutic efficacy, which concerns the optimal delivery of the stimulation, and its side effects, which suggest the need for selective stimulation. The medical devices currently in use are based on classic stimulation paradigms, 
with rectangular pulses with fixed parameters delivered on a bipolar or tripolar cuff electrode. Selective stimulation, VN activity recordings and closed-loop control of the stimulation parameters are some of the recent breakthroughs that, although not yet confirmed by large clinical studies, may drive the next-generation designs of medical devices. Plachta et al. (Plachta et al., 2014) described a very good example of such advances, in which selective stimulation and $\mathrm{VN}$ recordings together with an innovative multicontact electrode design led not only to the ability to modulate blood pressure without many side effects, but also to the selective recording of the baroreceptor synchronous activity.

\subsection{Selectivity and efficiency}

There are two types of efferent cardioinhibitory fibers in the VN, namely small myelinated B (or

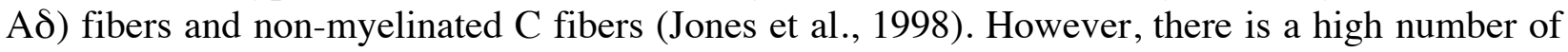
other fibers in the VN and their activation may cause side effects. In particular, activation of afferent A fibers has been implicated in seizure suppression in anti-epileptic VNS (Anholt et al., 2011), but activation of the A fibers branching to the laryngeal nerves leads to hoarseness. Thus, optimized VNS would selectively activate only a specified population of nerve fibers. Yet carrying out this task is difficult, because the thresholds for activation of $\mathrm{B}$ and $\mathrm{C}$ fibers are approximately 2-3 and 10-100 times greater, respectively, than the threshold of A fibers (Castoro et al., 2011). Nowadays, it seems impossible to activate $C$ fibers at very high-level electrical stimulation without causing side effects. Therefore, most of the research related to VNS in cardiac applications aims at selective activation of $\mathrm{B}$ or even $\mathrm{C}$ fibers with low activation of $\mathrm{A}$ fibers (Castoro et al., 2011, Anholt et al., 2011). A few approaches to solve this problem may be distinguished.

Minimizing charge required for activating $B$ and $C$ fibers using rectangular pulses, while minimizing side effects

This approach also minimizes both the risk of tissue damage and the energy requirements. Castoro et al. investigated the influence of various pulse widths and amplitudes, as well as two waveforms (monophasic vs. asymmetric charge-balanced biphasic) and three electrode configurations (monopolar cathode, bipolar with cathode proximally, and bipolar with cathode distally) on the recruitment of the A, B and C fibers in the right VN of the dog (Castoro et al., 2011). They concluded that neither the electrode configuration nor the stimulation waveform affected the recruitment of the different components of the compound action potential (CAP) and that pulse width had little influence on the normalized dynamic range of activation of $\mathrm{A}$ and $\mathrm{B}$ fibers. They also estimated that a $180-\mu$ s pulse width would allow activation of B fibers (but also A fibers) with the least amount of electrical charge.

\section{Modifying pulse shape in a way allowing for preferential activation of small fibers}

Quite a few techniques have been suggested for this purpose - for example, anodal block, highfrequency block, slowly rising pulses, and depolarizing prepulses. However, their effectiveness has usually been shown on peripheral nerves, which contain much fewer fibers compared with the VN trunk. Vuckovic et al. investigated three of these techniques (anodal block, slowly rising 
pulses, and depolarizing prepulses) in pig VN (Vuckovic et al., 2008). Suppression of the greatest fiber activity (expressed as a percentage of the maximum response) was $0-40 \%$ for anodal block, $10-25 \%$ for depolarizing prepulses and $40-50 \%$ for slowly rising pulses (with duration up to 5 $\mathrm{ms}$ ). The incomplete suppression of activation was mainly attributed to the large size of the VN trunk (3.0-3.5 mm), which resulted in a great difference in the excitation thresholds of nerve fibers at different distances from the electrode, as well as the relatively short duration of the slowly rising pulses. The techniques of slowly rising pulses and anodal block required comparable charges per phase, which were larger than for the technique of depolarizing prepulses and which exceeded the safety limits. Depolarizing prepulses were an optimal choice regarding the maximum required current and charge per phase, but were very sensitive to small changes in the current amplitude. Recently Irazoqui's team proposed the use of either chopped square pulses or doublets (Qing et al., 2015). They showed that C fibers could be elicited with half the charge needed with classical rectangular pulses with a relative decrease of about $10 \%$ of the activation of A fibers in a rat VN. This technique should be confirmed but may make it easier to elicit $\mathrm{C}$ fibers with an increase in selectivity - that is, a larger threshold difference.

To our knowledge, no one has thus far tested the application of the high-frequency conduction block for VNS. This is probably because of the issue of the onset response at the start of the stimulation, which would most likely cause a strong side effect.

\section{Modifying the electrode allowing preferential activation of the efferent fibers}

The rationale for doing so is that most undesired adverse effects during VNS for HF and obesity are caused by the activation of the afferent A fibers. This can be achieved by modifying the anodal block technique in which an asymmetrical cuff electrode is used. Such an approach is used in the CardioFit system (BioControl Medical Ltd, Yehudi, Israel), which is currently undergoing a multicenter randomized clinical trial (INOVATE-HF) (Hauptman et al., 2012); the clinical results have been discussed previously in (Gold et al., 2016). The effectiveness of this technique can possibly be further improved if quasi-trapezoid pulses are used (van den Honert and Mortimer, 1981). Using charge-balanced quasi-trapezoidal pulses driven through the CardioFit electrode (CSL), $63 \pm 13 \%$ unidirectional attenuation of the A fiber CAP was achieved in eight out of nine pigs (Anholt et al., 2011).

\section{Application of multi-contact electrode to preferentially activate fibers in a targeted region of the} nerve, so called spatial selectivity

To our knowledge, so far only Ordelman et al. (Ordelman, 2012, Ordelman et al., 2013) and Plachta et al. (Plachta et al., 2014) have investigated the use of this technique for VNS. Ordelman et al. compared bipolar stimulation in a single nerve cross-section using a multicontact cuff versus a tripolar ring electrode. Both types of cuff electrodes were compared with respect to their relative effects on the R-R interval (RRI), P-Q interval (PQI), left ventricular contractility (LVC) and left ventricular pressure (PLV) in seven pigs. Stimulation using the optimal bipolar configuration on the multicontact cuff significantly affected RRI, PQI, LVC and PLV, whereas stimulation with the ring electrode significantly affected only RRI and PQI. The cardiovascular parameters that could be significantly influenced varied between the bipolar configurations (Ordelman et al., 2013). These authors also observed in a similar experiment in awake pigs that the stimulation threshold for side effect was significantly higher with the multicontact cuff than 
with the ring electrode (Ordelman, 2012). Plachta et al. showed that longitudinal tripolar configurations for stimulation were able to limit side effects on bradycardia and bradypnea, whereas they had an action on blood pressure down to $60 \%$ in five rats (Plachta et al., 2014). They showed that selective VNS with longitudinal tripolar configurations was able to lower blood pressure and heart rate in an intensity- and pulse width- (with less homogeneity) dependent manner(Gierthmuehlen and Plachta, 2016). They concluded that baroreflex modulation with the combined effects of VNS and metoprolol medication was effective and still safe concerning bradycardia.

\section{Selectivity in gastric applications}

According to Hoffman (Hoffman and Schnitzlein, 1961), at least 97\% of the nerve fibers in the esophageal plexus are $\mathrm{C}$ fibers, with the remaining $3 \%$ being myelinated $\mathrm{A} \delta$ or B fibers. Since the esophageal plexus later forms the anterior and posterior gastric nerves (ventral and dorsal vagal trunks) supplying all abdominal organs and the gastrointestinal tract, it seems that it is mostly the $\mathrm{C}$ fibers in the $\mathrm{VN}$ that influence gastric function. It is therefore reasonable to target the $\mathrm{C}$ fibers, although this requires high currents, which may cause adverse effects. It should also be kept in mind that visceral primary afferent fibers may be unmyelinated peripherally and myelinated more centrally (but distal to the soma) (Duclaux et al., 1976).

In order to avoid activating the fibers innervating heart and lungs, in most cases the stimulation is delivered to the ventral and/or dorsal vagal trunk close to the esophagogastric junction (Camilleri et al., 2009, Val-Laillet et al., 2010b) - that is, below the place where the cardiac and pulmonary branches leave the VN.

There may be, however, two distinct objectives of $\mathrm{C}$ fiber stimulation:

- In most works and the 14 other publications listed in Table 1 of (Val-Laillet et al., 2010a) ), the objective was to activate the ascending $\mathrm{C}$ fibers in order to reduce appetite and induce a feeling of satiety. Although weight loss was observed in these cases, it is questionable whether the $\mathrm{C}$ fibers were activated, since Castoro et al. (Castoro et al., 2011) reported that the threshold for $\mathrm{C}$ fiber activation in the right $\mathrm{VN}$ of $\operatorname{dog}$ was $28 \mathrm{~mA}$ with a $300-\mu \mathrm{s}$ pulse width, whereas in the studies reported by Val-Laillet much lower charges were used. For example, (Pardo et al., 2007) used pulses of 0.25-1.50 mA and 0.25-0.50 ms, and (Matyja et al., 2004) applied pulses with pulse widths of $170 \mathrm{mV}$ and $170 \mathrm{~ms}$.

- Conversely, the objective of the VBLOC therapy is to block propagation of action potentials in $\mathrm{A} \delta$ and $\mathrm{C}$ fibers (Camilleri et al., 2009). Therefore, stimulation using a 5-kHz waveform of 1-6 mA amplitude was performed. It is nevertheless not clear whether this therapy was effective because the signals ascending to the brain were blocked or because the signals descending to the stomach, liver, pancreas, and small intestine were blocked (Richards, 2009). Furthermore, it is not even sure whether the propagation of action potentials in the $C$ fibers was blocked at all, since (Waataja et al., 2011) reported that when a similar waveform was used in the rat VN, 50\% attenuation of $\mathrm{C}$ wave was achieved between 7 and $7.5 \mathrm{~mA}$ (50\% blockade of the A $\delta$ fibers was obtained between 2 and $3 \mathrm{~mA}$ ). The results of EMPOWER, a randomized, double-blind, prospective study, showed that VBLOC stimulation was not more effective in obtaining excess weight loss than stimulation performed in the control group, which was stimulated with a much lower charge (less than $1,000^{\text {th }}$ of the charge delivered in the treated group) (Sarr et al., 2012).

Thus, although various selective VNS strategies have been proposed for weight reduction, it is 
not clear which fibers are activated when they are applied and what the associated mechanism is.

\subsection{Closed loop control in HF}

The VNS devices used in the major clinical trials for HF (INOVATE-HF, NECTAR-HF, ANTHEM-HF) do not integrate any system for the automatic adaptation of stimulation parameters. However, the device used in the INOVATE-HF study (Schwartz and De Ferrari, 2009) - that is, the Cardiofit system (BioControl Medical Ltd, Yehudi, Israel) - was designed to sense the heart rate (via an implanted intracardiac electrode) to deliver stimulation at preset delays from the R-wave. In order to avoid VNS-induced bradycardia, the stimulation is interrupted when heart rate drops below 55 bpm (De Ferrari et al., 2011). Nevertheless, this device does not include a cardiac stimulation feature, which would preserve cardiac function in the case of strong bradycardia. Conversely, the Equilia system (Sorin Group Italia, Saluggia, Italy) has a function to stimulate the heart in cases of bradycardia under a programmable value (VANGUARD trial, clinicaltrials.gov: NCT02113033). Other than this basic closed-loop function for avoiding severe bradycardia, there are currently no other implantable systems integrating closed-loop VNS control using cardiovascular signals as control variables.

To our knowledge, the first attempt at a closed-loop VNS approach was proposed by Bilgutay et al. (Bilgutay et al., 1968). In their paper, three models of "vagal tuners" were proposed. Two of them were based on implantable devices that were manually activated. The third was an external device, which was automatically activated when the RR interval fell below a threshold value. In such vagal tuners, VNS is delivered synchronously with the R-wave, detected from the ECG signal. Although the two manual approaches were developed and evaluated on ten dogs, no details were given on the development or evaluation of the automatic approach. Two closed-loop systems for VNS control, based on the adaptation of the VNS frequency, have been proposed (Waninger et al., 2000). A control system, based on the cumulative sum control chart technique, adjusted the stimulation frequency in order to regulate the average ventricular rate during atrial fibrillation in dogs (Waninger et al., 2000). VNS was delivered continuously to the left VN, without any cardiac beat synchronization. Initially, the stimulation was delivered at a nominal frequency of 1 pulse/s and then the controller automatically updated the left VNS frequency. The other stimulation parameters were manually defined and fixed during the entire test for each dog (pulse width $=1 \mathrm{~ms}$ and current $=2-5 \mathrm{~mA}$ ). Tosato et al. (Tosato et al., 2006) used a proportional-integral (PI) controller, which adjusted the stimulation frequency, in order to regulate heart rate in pigs. In their work, different tests were presented, including the stimulation of the left, right and both VNs. For each test, a different stimulation amplitude was kept constant in the range of $4-15 \mathrm{~mA}$, the pulse width was fixed to $0.3 \mathrm{~ms}$ and the controller automatically updated the "optimal" stimulation frequency within the range of $0-20 \mathrm{~Hz}$ in three pigs and $0-2 \mathrm{~Hz}$ in four pigs. The update rate of the controller was kept constant within a test, but varied for each test within 10-60 updates/s and the stimulation was delivered asynchronously. In the system proposed by Zhang et al. (Zhang et al., 2002), a PI controller was used to determine the instantaneous amplitude of the impulses applied for VNS. This closed-loop system was used to determine the hemodynamic changes at each level of ventricular rate and to establish the optimal anterograde ventricular rate during atrial fibrillation. More recently, a VNS closed-loop control system was proposed in order to regulate the heart rate of a sheep with induced HF on a beat-tobeat basis (Ugalde et al., 2014), but due to hardware constraints of the neuromodulator, only an on-off approach was implemented. The experimental results confirmed that the closed-loop VNS 
with the tested parameter configurations significantly modified the spontaneous RR interval. Nevertheless, the results showed significant RR oscillations, inherent to the on-off algorithm. Further works of the same group were directed toward implementing a more advanced control algorithm (PI controller) that effectively reduced these unwanted oscillations (Romero Ugalde et al., 2015). However, this approach has been limited to experimental studies, since this kind of controller is still too complex to be embedded in an implantable system.

It should be noted that most published VNS control approaches have been limited to the modulation of only one stimulation parameter (often the current amplitude). The influence of all other VNS parameters has thus not been exploited, although it has been shown that different combinations of VNS settings are associated with a large variety of autonomic responses and may lead to an improved response while minimizing side effects (Rousselet et al., 2014). The future of embedded closed-loop VNS thus relies on the development of novel, lightweight methods allowing modulation of the different VNS parameters as a function of a set of physiological or physical variables acquired by the device.

\subsection{VN activity monitoring}

The information traveling along the $\mathrm{VN}$ is deeply mixed as it comes from various sources. Consequently, multicontact recordings together with dedicated signal processing to extract the valuable pieces of information linked particularly to cardiac activity have been investigated in only a few studies. Neural recordings in peripheral nerves are typically in the range of a few $\mu \mathrm{V}$ (Nikolić et al., 1994) and remain challenging. However, electroneurogram (ENG) signals from the VN recorded with chronically implanted cuff electrodes can be used to predict epileptic seizures (Nielsen et al., 2008). Several authors have therefore identified either manually or automatically the recorded single contact signal that was most correlated with the targeted activity. In Plachta et al. (Plachta et al., 2012, Plachta et al., 2014), the baroreceptor compound activity was detected using multichannel cuff electrode recordings on rat vagal nerve. Performing coherent averaging evidenced the activity. In (Rozman and Ribarič, 2007), the single-channel channel that was best correlated with heart activity was identified using the spectrum estimation technique. In (Peclin and Rozman, 2014), electrically evoked CAPs were measured in an isolated segment of porcine cervical left VN with a 9x11 multicontact cuff (MCC) electrode. The authors managed to achieve fiber selectivity through VNS parameters and demonstrated fascicle discrimination during neural response recording.

Another option consists of combining the different electrode channels from an MCC electrode to create a virtual channel with enhanced characteristics. This decomposition can be archived using either data-driven approaches (Tesfayesus and Durand, 2007) that are based on the ENG signal statistics or inverse problem approaches.

Concerning data-driven approaches, (Cheng et al., 2005) applied principal component analysis on 4-channel bipolar recordings to estimate peroneal and tibial afferent activity in the sciatic nerve. In investigations on the same problematic, independent component analysis (ICA) was applied in (Tesfayesus and Durand, 2005, Tesfayesus and Durand, 2007) with the use of the FastICA algorithm: the influence of the number of sources and the permutation ambiguity inherent to ICA were addressed in these papers.

The identification of the neural activity of different fascicles within a nerve from the global activity of the nerve through MCC electrodes has been investigated by two main research teams: that of Popovic, Univ. of Aalborg and Univ. of Belgrade, and that of Durand, Univ. of Cleveland. 
For instance, Zariffa et al. identified nerve activation using a computational forward model simple enough to allow real-time processing (Zariffa, Nagai et al. 2011). They managed to localize active pathways with mean localization errors in the $150-180 \mu \mathrm{m}$ range (in a $720-\mu \mathrm{m}$ diameter endoneurium, with $10-\mu \mathrm{m}$ diameter individual fibers). However, the method suffered from numerous spurious pathways at moderately low noise levels (20\% additive noise).

The inverse problem is complex since the data are insufficient to identify a single source distribution. Moreover, the signal is corrupted by both exogenous and biological noise that is difficult to identify and model, and finally the inverse problem is ill-posed. Small errors may considerably hamper the estimation, and regularization methods should be used (Zariffa and Popovic, 2009). Hence computational methods developed for brain imaging have found their way to peripheral nerve imaging (Tesfayesus et al., 2004, Tesfayesus and Durand, 2005). Zariffa proposed to localize active pathways in peripheral nerves using the sLORETA method (Zariffa et al., 2009\} while Wodlinger used a beamforming approach for the same task (Wodlinger and Durand, 2009). Rieger et al. tried to increase the information rate by using a MCC associated with velocity-selective recordings (VSR) (Rieger et al., 2004, Rieger and Taylor, 2013). In VSR, a series of ring electrodes are positioned in the longitudinal direction of the nerve. The different pieces of information along the nerve are combined using delay-and-add signal techniques that filter signals depending on their propagation velocity and direction. In Yoshida and Horch, a MCC was used to record two types of elicited single-fiber action potentials (SFAPs) in an earthworm model: $14.9 \mathrm{~m} / \mathrm{s}$ and $6.9 \mathrm{~m} / \mathrm{s}$ (Yoshida and Horch, 1996).

\subsection{Technology}

\section{Electrode design}

The electrode is critical to measuring the ENG/CAP or applying neural stimulation. Neural electrodes can be placed either outside the nerve or intrafascicularly (penetrating the nerve, Table 4). Cuff electrodes present conductive contacts embedded in an insulating tube that surrounds the nerve. Multicontact electrode cuffs enable selective stimulation or measurement. Increasing the number of contacts and decreasing their size provides better spatial resolution and consequently improves the selectivity (Grill and Mortimer, 1996) both for recordings and stimulation. The cuff electrodes record ENG/CAP and do not allow access to SFAP, contrary to intrafascicular electrodes.

\begin{tabular}{|l|l|l|}
\hline Type & Features & Description \\
\hline $\begin{array}{l}\text { Flat interface nerve electrode (FINE) } \\
\text { Tyler and Durand, 2002) }\end{array}$ & Multi contact cuff, Silicone, Pt contact \\
\hline Utah array (BlackRock) & Intrafascicular electrodes up to 128 contacts & $\begin{array}{l}\text { The purpose is to flatten the nerve, for } \\
\text { increasing its surface. So the distance } \\
\text { between electrodes and fascicles is reduced, } \\
\text { allowing a closer access to the fascicles }\end{array}$ \\
$\begin{array}{l}\text { penetrate into a nerve fascicle and enable } \\
\text { selective activation of nerves This type of } \\
\text { electrode would enable more selective } \\
\text { activation, due to the short distance between } \\
\text { the contact and the fiber. }\end{array}$ \\
$\begin{array}{l}\text { TIME } \\
\begin{array}{l}\text { LIFE } \\
\text { (Yoshida and Horch, 1993, Djilas et al., 2009) } \\
\text { (Badia et al., 2011) }\end{array}\end{array}$ & $\begin{array}{l}\text { Up to 16 contacts inserted transversally } \\
\text { within the nerve, Polyimide, IrOx contacts } \\
\text { Typically } 8 \text { contacts inserted longitudinally } \\
\text { within the nerve, Pt contacts }\end{array}$ & $\begin{array}{l}\text { TIME May stimulate individual fascicles } \\
\text { Badia et al. shows differences between LIFE } \\
\text { TIME and cuff regarding selectivity. LIFE is } \\
\text { well suited for recording along few axons. }\end{array}$ \\
\hline
\end{tabular}

Table 4: non conventional types of electrodes for peripheral nerve stimulation 
The $\mathrm{VN}$ is one of the most important cranial nerves; damage can result in permanent voice changes, a defect in cardiac rhythm and breathing difficulties. Less invasive interfaces like cuff electrodes thus remain the best solution compared with intrafascicular electrodes or those that change the nerve shape like the FINE (Table 4). Flexible cuffs do not compress the nerve, thus minimal fibrosis and trauma appear (Rodriguez et al., 2000). For ENG recordings, the tripolar configuration is used to reject noise (Stein et al., 1975); associated with a differential amplifier, the common mode (artifacts from far-field signals like EMG ECG) is rejected. For VN stimulation and recording, (Ordelman, 2012, Ordelman et al., 2013) and (Plachta et al., 2014) used MCC to achieve spatial selectivity for both VN stimulation or recording.

For VNS applications, commercial electrodes are from Cyberonics (Houston, TX, USA): the helical electrodes are made of platinum ribbon with an open helical design. The electrodes are composed of three helical parts: one for cathode, one for anode, and one for anchoring (Amar et al., 2008). The electrode configuration is bipolar or tripolar. With a good seal, the cuff provides efficient stimulation by confining the stimulation current to the inner space of the electrode and avoiding current leak and crosstalk with other nerves and surrounding tissues (Loeb and Peck, 1996). However, for helical structures, its open shape explains its low selectivity (Agnew et al., 1989).

The contact impedance must be as low as possible to increase the signal to noise ratio (SNR). The choice of the material is critical; for instance, iridium oxide exhibits lower impedance than platinum. In addition, for stimulation, this material presents a much higher injection charge. Last, local amplification of the recording signal improves the SNR, using for example an RHA1016 preamplifier (Intan Technologies, UT, USA) (Tang et al., 2014).

The trend in neural electrical stimulation is toward systems with a high number of contacts to improve selectivity. The advantage of microelectrodes is their ability to stimulate a comparatively small volume of neural tissue and to record the ENG from a smaller population of fibers. MEMS technology combines high precision and small dimensions for the patterns and ensures good repeatability compared with the macroelectrodes manufactured manually. For measurement and stimulation, the variability of the impedance of the active area should be the smallest possible. Research groups have focused on flexible electrodes based on MEMS technology for less invasive approaches. The most frequently used polymer is polyimide (Rubehn and Stieglitz 2010, Plachta, Espinosa et al. 2012), which is well mastered and regularly used in MEMS technology. Polyimide can support temperatures up to $350^{\circ} \mathrm{C}$. Parylene is qualified for long-term human implants (Rodger, Fong et al. 2008, Kuo, Kim et al. 2013) and it possesses lower moisture absorption than polyimide, but it cannot handle such high temperatures. SU8 (Altuna, Bellistri et al. 2013) and liquid crystal polymer (Lee, Seo et al. 2009, Lee, Jun et al. 2012) are known for very low water absorption. (Hess, Dunning et al. 2007) investigated a new polymer Avatrel $^{\mathrm{TM}} /$ polynorbornene to manufacture a multicontact FINE-type electrode. This polymer, with its lower moisture absorption than polyimide, can be spin-coated and the metal layer is obtained by the liftoff process. The patterning is not performed by plasma etching with laser (Henle, Raab et al. 2011). The short-term cytotoxicity testing suggests that this material may be biocompatible.

A wide range of materials has been used for the active area, including stainless steel, tungsten, platinum, and platinum-iridium alloys. To increase the selectivity, the active surface decreases, which thus increases the charge density and impedance. Thus, new materials with higher injection charge limits and lower impedance have been investigated. The most popular ones are 
iridium oxide (Meyer et al., 2001, Soo Hyun et al., 2009), platinum, carbon nanotubes (SauterStarace et al., 2009, Musa et al., 2012), poly (ethylenedioxythiophene) (PEDOT) (Khodagholy et al., 2013), diamond (Maybeck et al., 2014), titanium nitride (Weiland et al., 2002). Platinum, currently used in implantable device, offers a limited reversible CSC: about 50-350 $\mu \mathrm{C} / \mathrm{cm}^{2}$, the iridium oxide provides $1200-3300 \mu \mathrm{C} / \mathrm{cm}^{2}$ (Merrill et al., 2005). It is not easy to compare the results because of the dependence on stimulation parameters. The charge injection limit measured by (Weiland et al., 2002) was $0.87 \mathrm{mC} / \mathrm{cm}^{2}$ for titanium nitride and $4 \mathrm{mC} / \mathrm{cm}^{2}$ for Iridium oxide. Packaging the flexible microelectrodes is also challenging, particularly with respect to wire bonding. For the fabrication of multichannel electrodes, multiple wires must be connected to small thin electrodes. Several packaging techniques have been reported: zero insertion force (Ziegler et al., 2006), the stud bump acting as rivet (Stieglitz et al., 2005), the ACF (Anisotropic Conductive Films) (Baek et al., 2011), commercial Merrill, two connectors (Omnetics Connectors Corporation, Minneapolis, USA), attached with conductive epoxy (Patrick et al., 2010). As the number of interconnections increases, the individual wires are replaced by flat flexible cables (FFC). The ribbon cables are conformable, and allow a collective approach for the electrical packaging.

The commercial electrodes are still mainly in silicone rubber with iridium platinum bulk. To improve the selectivity, the trend is toward MEMS electrodes with polymer substratum, but longterm implantation should confirm that these technologies remain reliable and efficient.

\section{Multi synchronous output stimulator}

For closed-loop control, particularly for HF, implantable VNS stimulators must embed at least a sensing stage to monitor changes in cardiac electrical activity, an output stage for stimulus generation, and a processor to compute the control algorithm. Closed-loop control is often limited to on/off control of the stimulus generator (BioControl Medical Ltd, Yehudi, Israel), this latter delivering a preprogrammed stimulation profile. Advanced closed-loop control, as previously described, relies on dynamically (real-time) adapting the stimulus after computing the next set of stimulation parameters according to a given control law - that is, an algorithm. These parameters are usually the frequency, pulse width and amplitude of a stimulus waveform that is often limited to rectangular biphasic pulses on bipolar or tripolar electrodes. Indeed, few multipolar stimulators allow for the configuration and real-time control of simulation parameters using several channels independently (i.e., independent current sources and not a global or "multiplexed" source) and supplying complex stimulation profiles. To do so, the stimulus generator must be able to deal with 1) the configuration of electrodes in terms of active contacts and their polarity (anode, cathode, high impedance), defined channel by channel (Guilvard et al., 2012), or as a global "virtual" electrode (Andreu et al., 2009), and 2) the configuration of the global current repartition between active poles ensuring current ratios on active poles so that the relative current distribution remains constant whatever the total injected current (Techer et al., 2004, Soulier et al., 2008, Guilvard et al., 2012, Liu et al., 2012). These are mandatory features when the aim is spatial and directional (multiple sources or sinks for field shaping) and fiber-type (current ratios) selective stimulation.

Although the impact of a multipolar electrode configuration has been demonstrated in several studies (Badia et al., 2011), no existing device to our knowledge allows for dynamically playing with the global electrode configuration, except to some extent the implantable versatile electrodedriving ASIC which is an output stage, without the microcontroller, dedicated to epidural 
stimulation (Giagka et al., 2015). This drastically increases the stimulator complexity since it requires both dynamically modifying the electrode configuration and accurately and independently controlling the injection of charges on a subset of contacts. But this modifies the paradigm of VNS stimulation since being able to dynamically - or more precisely, sequentially (i.e., interleaved stimulation) - select the multipolar electrode configuration also allows for combining several stimulation physiological effects on heart rhythm (in addition to modulating the frequency or the injected quantity of charges).

\section{Conclusion}

Clearly, VNS has a huge potential to treat numerous diseases linked to the autonomous nervous system, as already demonstrated for weight control and HF. It is already a well-established technique for treating epilepsy and other pathologies related to brain functions that can be neuromodulated. However, in order to use effective, safe and robust VNS, several issues, indexed in this state-of-the-art review, still remain to be elucidated. Encouraging new techniques of stimulation and recordings should nevertheless drastically improve and broaden VNS applications in the near future.

\section{Acknowledgement}

This review is issued from a consortium work within the INTENSE project, partially supported by BPI France within the "Investments for the Future" program in France.

\section{References}

AARONSON, S. T., CARPENTER, L. L., CONWAY, C. R., REIMHERR, F. W., LISANBY, S. H., SCHWARTZ, T. L., MORENO, F. A., DUNNER, D. L., LESEM, M. D., THOMPSON, P. M., HUSAIN, M., VINE, C. J., BANOV, M. D., BERNSTEIN, L. P., LEHMAN, R. B., BRANNON, G. E., KEEPERS, G. A., O'REARDON, J. P., RUDOLPH, R. L. \& BUNKER, M. 2013. Vagus nerve stimulation therapy randomized to different amounts of electrical charge for treatment-resistant depression: acute and chronic effects. Brain stimulation, 6, 631-640.

ABELL, T. L., CHEN, J., eMMANUEL, A., JOLLEY, C., SARELA, A. I. \& TORNBLOM, H. 2015. Neurostimulation of the gastrointestinal tract: review of recent developments. Neuromodulation, 18, 221-227.

AGNEW, W. F., MCCREERY, D. B., YUEN, T. G. \& BULLARA, L. A. 1989. Histologic and physiologic evaluation of electrically stimulated peripheral nerve: considerations for the selection of parameters. Annals of biomedical engineering, 17, 39-60.

ALTUNA, A., BELLISTRI, E., CID, E., AIVAR, P., GAL, B., BERGANZO, J., GABRIEL, G., GUIMERA, A., VILLA, R., FERNANDEZ, L. J. \& MENENDEZ DE LA PRIDA, L. 2013. Based microprobes for simultaneous neural depth recording and drug delivery in the brain. Lab on a chip, 13, 1422-1430. 
AMAR, A. P., APUZZO, M. L. \& LIU, C. Y. 2008. Vagus nerve stimulation therapy after failed cranial surgery for intractable epilepsy: results from the vagus nerve stimulation therapy patient outcome registry. Neurosurgery, 62, 506-513.

ANDREU, D., GUIRAUD, D. \& SOUQUET, G. 2009. A distributed architecture for activating the peripheral nervous system. Journal of neural engineering, 6, 026001.

ANHOLT, T. A., AYAL, S. \& GOLDBERG, J. A. 2011. Recruitment and blocking properties of the CardioFit stimulation lead. Journal of Neural Engineering, 8, 1-7.

ANNONI, E. M., XIE, X., LEE, S. W., LIBBUS, I., KENKNIGHT, B. H., OSBORN, J. W. \& TOLKACHEVA, E. G. 2015. Intermittent electrical stimulation of the right cervical vagus nerve in salt-sensitive hypertensive rats: effects on blood pressure, arrhythmias, and ventricular electrophysiology. 3, e12476.

AVID INVESTIGATORS 1997. A comparison of antiarrhythmic-drug therapy with implantable defibrillators in patients resuscitated from near-fatal ventricular arrhythmias. The Antiarrhythmics versus Implantable Defibrillators (AVID) Investigators. 337, 1576-1583.

AY, I., NAPADOW, V. \& AY, H. 2014. Electrical stimulation of the vagus nerve dermatome in the external ear is protective in rat cerebral ischemia. Brain stimulation, 8, 7-12.

AY, I., NASSER, R., SIMON, B. \& AY, H. 2015. Transcutaneous cervical vagus nerve stimulation ameliorates acute ischemic injury in rats. Brain stimulation, 9, 166-173.

BADIA, J., BORETIUS, T., ANDREU, D., AZEVEDO-COSTE, C., STIEGliTZ, T. \& NAVARRO, X. 2011. Comparative analysis of transverse intrafascicular multichannel, longitudinal intrafascicular and multipolar cuff electrodes for the selective stimulation of nerve fascicles. Journal of neural engineering, 8, 036023.

BAEK, D. H., PARK, J. S., LEE, E. J., SHIN, S., MOON, J. H., PAK, J. J. \& LEE, S. H. 2011. Interconnection of multichannel polyimide electrodes using anisotropic conductive films (ACFs) for biomedical applications. IEEE transactions on bio-medical engineering, 58, 1466-1473.

BAILEY, P. \& BREMER, F. 1938. A sensory cortical representation of the vagus nerve. 1, 405-412.

BAJBOUJ, M., MERKL, A., SCHLAEPfER, T. E., FRICK, C., ZOBEL, A., MAIER, W., O'KEANE, V., CORCORAN, C., ADOLFSSON, R., TRIMBLE, M., RAU, H., HOFF, H. J., PADBERG, F., MULLERSIECHENEDER, F., AUDENAERT, K., VAN DEN, A. D., MATTHEWS, K., CHRISTMAS, D., ELJAMEL, S. \& HEUSER, I. 2010. Two-year outcome of vagus nerve stimulation in treatment-resistant depression. Journal of Clinical Psychopharmacology, 30, 273-281.

BARONE, L., COLICCHIO, G., POLICICCHIO, D., DI CLEMENTE, F., DI MONACO, A., MEGLIO, M., LANZA, G. A. \& CREA, F. 2007. Effect of vagal nerve stimulation on systemic inflammation and cardiac autonomic function in patients with refractory epilepsy. Neuroimmunomodulation, 14, 331-336.

BEAUMONT, E., SOUTHERLAND, E. M., HARDWICK, J. C., WRIGHT, G. L., RYAN, S., LI, Y., KENKNIGHT, B. H., ARMOUR, J. A. \& ARDELL, J. L. 2015. Vagus nerve stimulation mitigates intrinsic cardiac neuronal and adverse myocyte remodeling post myocardial infarction. 309, H1198-1206.

BEN-MENACHEM, E., MANON-ESPAILLAT, R., RISTANOVIC, R., WILDER, B. J., STEFAN, H., MIRZA, W., TARVER, W. B. \& WERNICKE, J. F. 1994. Vagus nerve stimulation for treatment of partial seizures: 1. A controlled study of effect on seizures. First international vagus nerve stimulation study group. Epilepsia, 35, 616-626. 
BILGUTAY, A. M., BILGUTAY, I. M., MERKEL, F. K. \& LILLEHEI, C. W. 1968. Vagal tuning. A new concept in the treatment of supraventricular arrhythmias, angina pectoris, and heart failure. The Journal of Thoracic and Cardiovascular Surgery, 56, 71-82.

BILLMAN, G. E., SCHWARTZ, P. J. \& STONE, H. L. 1982. Baroreceptor reflex control of heart rate: a predictor of sudden cardiac death. Circulation, 66, 874-880.

BIRABEN, A., CHAUVIN, A., GUERIN, S. \& MALBERT, C.-H. 2005. Chronic vagal stimulation correlates with activation of specific subcortical regions. Neurogastroenterology \& Motility, 17, 11-12.

BIRABEN, A., GUERIN, S., BOBILLER, E., VAL-LAILLET, D. \& MALBERT, C.-H. 2008. Activation centrale à la suite d'une stimulation vagale chronique chez le porc - apports de l'imagerie fonctionnelle. 161, 441-448.

BODENLOS, J. S., KOSE, S., BORCKARDT, J. J., NAHAS, Z., SHAW, O'NEIL, P. M., PAGOTO, S. L. \& GEORGE, M. S. 2007. Vagus nerve stimulation and emotional responses to food among depressed patients. Journal of diabetes science and technology, 1, 771-779.

BOGALE, N., PRIORI, S., CLELAND, J. G., BRUGADA, J., LINDE, C., AURICCHIO, A., VAN VELDHUISEN, D. J., LIMBOURG, T., GITT, A., GRAS, D., STELLBRINK, C., GASPARINI, M., METRA, M., DERUMEAUX, G., GADLER, F., BUGA, L., DICKSTEIN, K., SCIENTIFIC COMMITTEE, N. C. \& INVESTIGATORS 2012. The European CRT survey: 1 year (9-15 months) follow-up results. European journal of heart failure, 14, 61-73.

BOHDJALIAN, A., PRAGER, G., AVIV, R., POLICKER, S., SCHINDLER, K., KRETSCHMER, S., RIENER, R., ZACHERL, J. \& LUDVIK, B. 2006. One-year experience with Tantalus: a new surgical approach to treat morbid obesity. Obesity surgery, 16, 627-634.

BOHM, M., SWEDBERG, K., KOMAJDA, M., BORER, J. S., FORD, I., DUBOST-BRAMA, A., LEREBOURS, G. \& TAVAZZI, L. 2010. Heart rate as a risk factor in chronic heart failure (SHIFT): the association between heart rate and outcomes in a randomised placebo-controlled trial. Lancet, 376, 886-894.

BONAZ, B., PICQ, C., SINNIGER, V., MAYOL, J. F. \& CLARENCON, D. 2013. Vagus nerve stimulation: from epilepsy to the cholinergic anti-inflammatory pathway. Neurogastroenterology and motility: the official journal of the European Gastrointestinal Motility Society, 25, 208-221.

BONAZ, B., SINNIGER, V., HOFFMANN, D., CLARENCON, D., MATHIEU, N., DANTZER, C., VERCUEIL, L., PICQ, C., TROCME, C., FAURE, P., CRACOWSKI, J. L. \& PELLISSIER, S. 2016. Chronic vagus nerve stimulation in Crohn's disease: a 6-month follow-up pilot study. Neurogastroenterology and Motility, Feb 27.

BORETIUS, T., BADIA, J., PASCUAL-FONT, A., SCHUETTLER, M., NAVARRO, X., YOSHIDA, K. \& STIEGLITZ, T. 2010. A transverse intrafascicular multichannel electrode (TIME) to interface with the peripheral nerve. Biosensors \& bioelectronics, 26, 62-69.

BOROVIKOVA, L. V., IVANOVA, S., ZHANG, M., YANG, H., BOTCHKINA, G. I., WATKINS, L. R., WANG, H., ABUMRAD, N., EATON, J. W. \& TRACEY, K. J. 2000. Vagus nerve stimulation attenuates the systemic inflammatory response to endotoxin. Nature, 405, 458-462.

BRACK, K. E., COOTE, J. H. \& NG, G. A. 2011. Vagus nerve stimulation protects against ventricular fibrillation independent of muscarinic receptor activation. Cardiovascular research, 91, 437-446.

BRACK, K. E., PATEL, V. H., COOTE, J. H. \& NG, G. A. 2007. Nitric oxide mediates the vagal protective effect on ventricular fibrillation via effects on action potential duration restitution in the rabbit heart. The Journal of physiology, 583, 695-704. 
BRAY, G. A. 2000. Afferent signals regulating food intake. The Proceedings of the Nutrition Society, 59, 373-384.

BRIGNOLE, M., AURICCHIO, A., BARON-ESQUIVIAS, G., BORDACHAR, P., BORIANI, G., BREITHARDT, O. A., CLELAND, J., DEHARO, J. C., DELGADO, V., ELLIOTT, P. M., GORENEK, B., ISRAEL, C. W., LECLERCQ, C., LINDE, C., MONT, L., PADELETTI, L., SUTTON, R., VARDAS, P. E., ZAMORANO, J. L., ACHENBACH, S., BAUMGARTNER, H., BAX, J. J., BUENO, H., DEAN, V., DEATON, C., EROL, C., FAGARD, R., FERRARI, R., HASDAI, D., HOES, A. W., KIRCHHOF, P., KNUUTI, J., KOLH, P., LANCELLOTTI, P., LINHART, A., NIHOYANNOPOULOS, P., PIEPOLI, M. F., PONIKOWSKI, P., SIRNES, P. A., TAMARGO, J. L., TENDERA, M., TORBICKI, A., WIJNS, W., WINDECKER, S., KIRCHHOF, P., BLOMSTROM-LUNDQVIST, C., BADANO, L. P., ALIYEV, F., BANSCH, D., BAUMGARTNER, H., BSATA, W., BUSER, P., CHARRON, P., DAUBERT, J. C., DOBREANU, D., FAERESTRAND, S., HASDAI, D., HOES, A. W., LE HEUZEY, J. Y., MAVRAKIS, H., MCDONAGH, T., MERINO, J. L., NAWAR, M. M., NIELSEN, J. C., PIESKE, B., POPOSKA, L., RUSCHITZKA, F., TENDERA, M., VAN GELDER, I. C. \& WILSON, C. M. 2013. Guidelines on cardiac pacing and cardiac resynchronization therapy: the Task Force on cardiac pacing and resynchronization therapy of the European Society of Cardiology (ESC). Developed in collaboration with the European Heart Rhythm Association (EHRA). 34, 2281-2329.

BRISTOW, M. R. 1984. The adrenergic nervous system in heart failure. 311, 850-851.

BRISTOW, M. R., SAXON, L. A., BOEHMER, J., KRUEGER, S., KASS, D. A., DE MARCO, T., CARSON, P., DEMETS, D., WHITE, B. G., DEVRIES, D. W. \& FELDMAN, A. M. 2004. Cardiac-resynchronization therapy with or without an implantable defibrillator in advanced chronic heart failure. 350, 21402150.

CAI, P. Y., BODHIT, A., DEREQUITO, R., ANSARI, S., ABUKHALIL, F., THENKABAIL, S., GANJI, S., SARAVANAPAVAN, P., SHEKAR, C. C., BIDARI, S., WATERS, M. F. \& HEDNA, V. S. 2014. Vagus nerve stimulation in ischemic stroke: old wine in a new bottle. Frontiers in neurology, 5, 107.

CALVILLO, L., VANOLI, E., ANDREOLI, E., BESANA, A., OMODEO, E., GNECCHI, M., ZERBI, P., VAGO, G., BUSCA, G. \& SCHWARTZ, P. J. 2011. Vagal stimulation, through its nicotinic action, limits infarct size and the inflammatory response to myocardial ischemia and reperfusion. Journal of cardiovascular pharmacology, 58, 500-507.

CAMILLERI, M., TOOULI, J., HERRERA, M. F., KOW, L., PANTOJA, J. P., BILLINGTON, C. J., TWEDEN, K. S., WILSON, R. R. \& MOODY, F. G. 2009. Selection of electrical algorithms to treat obesity with intermittent vagal block using an implantable medical device. Surgery for obesity and related diseases : official journal of the American Society for Bariatric Surgery, 5, 224-229.

CAMILleRI, M., TOOULI, J., HERRERA, M. F., KULSENG, B., KOW, L., PANTOJA, J. P., MARVIK, R., JOHNSEN, G., BILLINGTON, C. J., MOODY, F. G., KNUDSON, M. B., TWEDEN, K. S., VOLLMER, M., WILSON, R. R. \& ANVARI, M. 2008. Intra-abdominal vagal blocking (VBLOC therapy): clinical results with a new implantable medical device. Surgery, 143, 723-731.

CASTORO, M. A., YOO, P. B., HINCAPIE, J. G., HAMANN, J. J., RUBLE, S. B., WOLF, P. D. \& GRILL, W. M. 2011. Excitation properties of the right cervical vagus nerve in adult dogs. Experimental Neurology, 227, 62-68.

CAZeAu, S., LeClercQ, C., LAVergne, T., WALKer, S., VARMA, C., Linde, C., GARRIGUe, S., KAPPENBERGER, L., HAYWOOD, G. A., SANTINI, M., BAILLEUL, C. \& DAUBERT, J. C. 2001. Effects of multisite biventricular pacing in patients with heart failure and intraventricular conduction delay. $344,873-880$. 
CHA, R., MARESCAUX, J. \& DIANA, M. 2014. Updates on gastric electrical stimulation to treat obesity: Systematic review and future perspectives. World journal of gastrointestinal endoscopy, 6, 419-431.

CHAKRAVARTHY, K., CHAUDHRY, H., WILLIAMS, K. \& CHRISTO, P. J. 2015. Review of the uses of vagal nerve stimulation in chronic pain management. Current pain and headache reports, 19, 54.

CHAVEL, S. M., WESTERVELD, M. \& SPENCER, S. 2003. Long-term outcome of vagus nerve stimulation for refractory partial epilepsy. 4, 302-309.

CHEN, J. 2004. Mechanisms of action of the implantable gastric stimulator for obesity. Obesity surgery, 14 Suppl 1, S28-32.

CHEN, M., ZHOU, X., YU, L., LIU, Q., SHENG, X., WANG, Z., WANG, S., JIANG, H. \& ZHOU, S. 2015. LoWlevel vagus nerve stimulation attenuates myocardial ischemic reperfusion injury by antioxidative stress and antiapoptosis reactions in canines. Journal of cardiovascular electrophysiology, 27, 224231.

CHEN, P. S., CHEN, L. S., FISHBEIN, M. C., LIN, S. F. \& NATTEL, S. 2014. Role of the autonomic nervous system in atrial fibrillation: pathophysiology and therapy. Circulation research, 114, 1500-1515.

CHENG, H. S., JU, M. S. \& LIN, C. C. 2005. Estimation of peroneal and tibial afferent activity from a multichannel cuff placed on the sciatic nerve. Muscle \& Nerve, 32, 589-599.

CHILDS, J. E., ALVAREZ-DIEPPA, A. C., MCINTYRE, C. K. \& KROENER, S. 2015. Vagus nerve stimulation as a tool to induce plasticity in pathways relevant for extinction learning. Journal of visualized experiments : JoVE, 102, e53032.

CHUNCHAI, T., SAMNIANG, B., SRIPETCHWANDEE, J., SILAPAWITATORN, K., KENKNIGHT, B. H., CHATTIPAKORN, N. \& CHATTIPAKORN, S. C. 2015. Vagus nerve stimulation restores cognitive function impaired by chronic obese-insulin resistant rats. Alzheimer's \& Dementia, 11, P497-P498.

CLANCY, J. A., MARY, D. A., WITTE, K. K., GREENWOOD, J. P., DEUCHARS, S. A. \& DEUCHARS, J. 2014. Non-invasive vagus nerve stimulation in healthy humans reduces sympathetic nerve activity. Brain stimulation, 7, 871-877.

CLARK, K. B., NARITOKU, D. K., SMITH, D. C., BROWNING, R. A. \& JENSEN, R. A. 1999. Enhanced recognition memory following vagus nerve stimulation in human subjects. Nature Neuroscience, 2, 94-98.

COHN, A. E. \& LEWIS, T. 1913. The predominant influence of the left vagus nerve upon conduction between the auricles and the ventricles in the dog. The Journal of experimental medicine, 18, 739747.

CONSENSUS INVESTIGATORS 1987. Effects of enalapril on mortality in severe congestive heart failure. Results of the Cooperative North Scandinavian Enalapril Survival Study (CONSENSUS). The CONSENSUS Trial Study Group. 316, 1429-1435.

CONWAY, C. R., CHIBNALL, J. T., GEBARA, M. A., PRICE, J. L., SNYDER, A. Z., MINTUN, M. A., CRAIG, A. D., CORNELL, M. E., PERANTIE, D. C. \& GIUFFRA, L. A. 2013. Association of cerebral metabolic activity changes with vagus nerve stimulation antidepressant response in treatment-resistant depression. Brain Stimulation, 6, 788-797.

COPELAND, J. G., SMITH, R. G., ARABIA, F. A., NOLAN, P. E., SETHI, G. K., TSAU, P. H., MCCLELLAN, D. \& SLEPIAN, M. J. 2004. Cardiac replacement with a total artificial heart as a bridge to transplantation. 351, 859-867. 
CORNING, J. 1883. Considerations on pathology and therapeutics of epilepsy. The Journal of Nervous and Mental Disease, 10, 243-248.

COWIE, M. R., WOOD, D. A., COATS, A. J., THOMPSON, S. G., POOLE-WILSON, P. A., SURESH, V. \& SUTTON, G. C. 1999. Incidence and aetiology of heart failure; a population-based study. 20, 421-428.

DABAN, C., MARTINEZ-ARAN, A., CRUZ, N. \& VIETA, E. 2008. Safety and efficacy of vagus nerve stimulation in treatment-resistant depression. A systematic review. Journal of affective disorders, 110, 1-15.

DAVIES, M., HOBBS, F., DAVIS, R., KENKRE, J., ROALFE, A. K., HARE, R., WOSORNU, D. \& LANCASHIRE, R. J. 2001. Prevalence of left-ventricular systolic dysfunction and heart failure in the Echocardiographic Heart of England Screening study: a population based study. Lancet, 358, 439444.

DAWSON, J., PIERCE, D., DIXIT, A., KIMBERLEY, T. J., ROBERTSON, M., TARVER, B., HILMI, O., MCLEAN, J., FORBES, K., KILGARD, M. P., RENNAKER, R. L., CRAMER, S. C., WALTERS, M. \& ENGINEER, N. 2016. Safety, feasibility, and efficacy of vagus nerve stimulation paired with upper-limb rehabilitation after ischemic stroke. Stroke; a journal of cerebral circulation, 47, 143-150.

DE COUCK, M., NIJS, J. \& GIDRON, Y. 2014. You may need a nerve to treat pain: the neurobiological rationale for vagal nerve activation in pain management. The Clinical journal of pain, 30, 1099-1105.

DE FERRARI, G. M., CRIJNS, H. J. G. M., BORGgREFE, M., MILASINOVIC, G., SMID, J., ZABEL, M., GAVAZZI, A., SANZO, A., DENNERT, R., KUSCHYK, J., RASPOPOVIC, S., KLEIN, H., SWEDBERG, K. \& SCHWARTZ, P. J. 2011. Chronic vagus nerve stimulation: a new and promising therapeutic approach for chronic heart failure. European Heart Journal, 32, 847-855.

DEL RIO, C. L., DAWSON, T. A., CLYMER, B. D., PATERSON, D. J. \& BILLMAN, G. E. 2008. Effects of acute vagal nerve stimulation on the early passive electrical changes induced by myocardial ischaemia in dogs: heart rate-mediated attenuation. Experimental physiology, 93, 931-944.

DELL, P. \& OLSON, R. 1951. Thalamic, cortical and cerebellar projections of vagal visceral afferences. $145,1084-1088$.

DIDIER, C., SONIA, P., VALÉRIE, S., ASTRID, K., DOMINIQUE, H., LAURENT, V., OLIVIER, D. \& BRUNO, B. 2014. Long term effects of low frequency $(10 \mathrm{~Hz})$ vagus nerve stimulation on EEG and heart rate variability in Crohn's disease: A case report. Brain Stimulation, 7, 914-916.

DJILAS, M., AZEVEDO-COSTE, C., GUIRAUD, D. \& YOSHIDA, K. 2009. Interpretation of muscle spindle afferent nerve response to passive muscle stretch recorded with thin-film longitudinal intrafascicular electrodes. IEEE transactions on neural systems and rehabilitation engineering : a publication of the IEEE Engineering in Medicine and Biology Society, 17, 445-453.

DUCLAUX, R., MEI, N. \& RANIERI, F. 1976. Conduction velocity along the afferent vagal dendrites: A new type of fibre. 260, 487-495.

ELLIOTT, R. E., MORSI, A., KALHORN, S. P., MARCUS, J., SELLIN, J., KANG, M., SILVERBERG, A., RIVERA, E., GELLER, E., CARLSON, C., DEVINSKY, O. \& DOYLE, W. K. 2011. Vagus nerve stimulation in 436 consecutive patients with treatment-resistant epilepsy: Long-term outcomes and predictors of response. Epilepsy \& Behavior, 20, 57-63.

ELLRICH, J. 2011. Transcutaneous vagus nerve stimulation. European Neurological Review, 6, 254-256. 
ERIKSSON, H., SVARDSUDD, K., LARSSON, B., OHLSON, L. O., TIBBLIN, G., WELIN, L. \& WILHELMSEN, L. 1989. Risk factors for heart failure in the general population: the study of men born in 1913. 10 , 647-656.

FAVRetTI, F., DE LUCA, M., SEgAto, G., BUSETto, L., CEOLONI, A., MAGON, A. \& ENZI, G. 2004. Treatment of morbid obesity with the Transcend Implantable Gastric Stimulator (IGS): a prospective survey. Obesity surgery, 14, 666-670.

FELDMAN, R. L., DUNNER, D. L., MULLER, J. S. \& STONE, D. A. 2013. Medicare patient experience with vagus nerve stimulation for treatment-resistant depression. Journal of medical economics, 16, 6274.

FERGUSON, D. W., BERG, W. J. \& SANDERS, J. S. 1990. Clinical and hemodynamic correlates of sympathetic nerve activity in normal humans and patients with heart failure: evidence from direct microneurographic recordings. Journal of the American College of Cardiology, 16, 1125-1134.

FLORAS, J. S. 2009. Should sleep apnoea be a specific target of therapy in chronic heart failure? Heart, 95, 1041-1046.

FOX, K., FORD, I., STEG, P. G., TENDERA, M. \& FERRARI, R. 2008. Ivabradine for patients with stable coronary artery disease and left-ventricular systolic dysfunction (BEAUTIFUL): a randomised, doubleblind, placebo-controlled trial. Lancet, 372, 807-816.

FURMAGA, H., CARRENO, F. R. \& FRAZER, A. 2012. Vagal nerve stimulation rapidly activates brainderived neurotrophic factor receptor TrkB in rat brain. PLoS One, 7, e34844.

GEORGE, M. S. \& ASTON-JONES, G. 2010. Noninvasive techniques for probing neurocircuitry and treating illness: vagus nerve stimulation (VNS), transcranial magnetic stimulation (TMS) and transcranial direct current stimulation (tDCS). Neuropsychopharmacology, 35, 301-316.

GEORGE, M. S., RUSH, A. J., MARANGELL, L. B., SACKEIM, H. A., BRANNAN, S. K., DAVIS, S. M., HOWLAND, R., KLING, M. A., MORENO, F., RITTBERG, B., DUNNER, D., SCHWARTZ, T., CARPENTER, L., BURKE, M., NINAN, P. \& GOODNICK, P. J. 2005. A one-year comparison of vagus nerve stimulation with treatment as usual for treatment-resistant depression. Biological psychiatry, 58, 364-373.

GEORGE, M. S., SACKEIM, H. A., RUSH, A. J., MARANGELL, L. B., NAHAS, Z., HUSAIN, M. M., LISANBY, S., BURT, T., GOLDMAN, J. \& BALLENGER, J. C. 2000. Vagus nerve stimulation: a new tool for brain research and therapy. Biological Psychiatry, 47, 287-295.

GIAGKA, V., EDER, C., DONALDSON, N. \& DEMOSTHENOUS, A. 2015. An implantable versatile electrode-driving ASIC for chronic epidural stimulation in rats. IEEE transactions on biomedical circuits and systems, 9, 387-400.

GIERTHMUEHLEN, M. \& PLACHTA, D. T. 2015. Effect of selective vagal nerve stimulation on blood pressure, heart rate and respiratory rate in rats under metoprolol medication. Hypertension research : official journal of the Japanese Society of Hypertension, 39, 79-87.

GIERTHMUEHLEN, M. \& PLACHTA, D. T. 2016. Effect of selective vagal nerve stimulation on blood pressure, heart rate and respiratory rate in rats under metoprolol medication. Hypertension research : official journal of the Japanese Society of Hypertension, 39, 79-87.

GOLD, M. R., VAN VELDHUISEN, D. J., HAUPTMAN, P. J., BORGGREFE, M., KUBO, S. H., LIEBERMAN, R. A., MILASINOVIC, G., BERMAN, B. J., DJORDJEVIC, S., NEELAGARU, S., SCHWARTZ, P. J., STARLING, R. C. \& MANN, D. L. 2016. Vagus nerve stimulation for the treatment of heart failure: the INOVATE-HF trial. Journal of the American College of Cardiology, (in press). 
GOODNICK, P. J., RUSH, A. J., GEORGE, M. S., MARANGELL, L. B. \& SACKEIM, H. A. 2001. Vagus nerve stimulation in depression. Expert Opinion on Pharmacotherapy, 2, 1061-1063.

GORTZ, L., BJORKMAN, A. C., ANDERSSON, H. \& KRAL, J. G. 1990. Truncal vagotomy reduces food and liquid intake in man. Physiology \& behavior, 48, 779-781.

GREENWAY, F. \& ZHENG, J. 2007. Electrical stimulation as treatment for obesity and diabetes. Journal of diabetes science and technology, 1, 251-259.

GRILL, W. M. \& MORTIMER, J. T. 1996. Quantification of recruitment properties of multiple contact cuff electrodes. IEEE Transactions on Rehabilitation Engineering, 4, 49-62.

GRIMONPREZ, A., RAEDT, R., PORTELLI, J., DAUWE, I., LARSEN, L. E., BOUCKAERT, C., DELBEKE, J., CARRETTE, E., MEURS, A., DE HERDT, V., BOON, P. \& VONCK, K. 2015. The antidepressant-like effect of vagus nerve stimulation is mediated through the locus coeruleus. 68, 1-7.

GROVES, D. \& BROWN, V. J. 2005. Vagal nerve stimulation: a review of its applications and potential mechanisms that mediate its clinical effects. Neuroscience and biobehavioral reviews, 29, 493-500.

GUILVARD, A., EFTEKHAR, A., SONG, L., TOUMAZOU, C. \& CONSTANDINOU, T. G. A fullyprogrammable neural interface for multi-polar, multi-channel stimulation strategies. IEEE International Symposium on Circuits and Systems, 20-23 May 20122012 Seoul. 2235-2238.

HAMANN, J. J., RUBLE, S. B., STOLEN, C., WANG, M., GUPTA, R. C., RASTOGI, S. \& SABBAH, H. N. 2013. Vagus nerve stimulation improves left ventricular function in a canine model of chronic heart failure. European journal of heart failure, 15, 1319-1326.

HAMLIN, R. L. \& SMITH, C. R. 1968. Effects of vagal stimulation on S-A and A-V nodes. The American journal of physiology, 215, 560-568.

HAUPTMAN, P. J., SCHWARTZ, P. J., GOLD, M. R., BORGGREFE, M., VAN VELDHUISEN, D. J., STARLING, R. C. \& MANN, D. L. 2012. Rationale and study design of the increase of vagal tone in heart failure study: INOVATE-HF. American heart journal, 163, 954-962.

HAYS, S. A., KHODAPARAST, N., HULSEY, D. R., RUIZ, A., SLOAN, A. M., RENNAKER, R. L., 2ND \& KILGARD, M. P. 2014. Vagus nerve stimulation during rehabilitative training improves functional recovery after intracerebral hemorrhage. Stroke; a journal of cerebral circulation, 45, 3097-3100.

HENLE, C., RAAB, M., CORDEIRO, J. G., DOOSTKAM, S., SCHULZE-BONHAGE, A., STIEGLITZ, T. \& RICKERT, J. 2011. First long term in vivo study on subdurally implanted micro-ECoG electrodes, manufactured with a novel laser technology. Biomedical microdevices, 13, 59-68.

HESS, A. E., DUNNING, J. L., TYLER, D. J. \& ZORMAN, C. A. A polynorbornene-based microelectrode array for neural interfacing. TRANSDUCERS - International Solid-State Sensors, Actuators and Microsystems Conference, 10-14 June 20072007 Lyon. 1235-1238.

HO, J. E., LARSON, M. G., GHORBANI, A., CHENG, S., COGLIANESE, E. E., VASAN, R. S. \& WANG, T. J. 2014. Long-term cardiovascular risks associated with an elevated heart rate: the Framingham Heart Study. Journal of the American Heart Association, 3, e000668.

HOFFMAN, H. H. \& SCHNITZLEIN, H. N. 1961. The numbers of nerve fibers in the vagus nerve of man. The Anatomical record, 139, 429-435.

HORBACH, T., THALHEIMER, A., SEYFRIED, F., ESCHENBACHER, F., SCHUHMANN, P. \& MEYER, G. 2015. abiliti Closed-loop gastric electrical stimulation system for treatment of obesity: Clinical results with a 27-month follow-up. 25, 1779-1787. 
HORD, E. D., EVANS, M. S., MUEED, S., ADAMOLEKUN, B. \& NARITOKU, D. K. 2003. The effect of vagus nerve stimulation on migraines. 4, 530-534.

HUANG, J., QIAN, J., YAO, W., WANG, N., ZHANG, Z., CAO, C., SONG, B. \& ZHANG, Z. 2014. Vagus nerve stimulation reverses ventricular electrophysiological changes induced by hypersympathetic nerve activity. Exp Physiol.

HUANG, J., QIAN, J., YAO, W., WANG, N., ZHANG, Z., CAO, C., SONG, B. \& ZHANG, Z. 2015. Vagus nerve stimulation reverses ventricular electrophysiological changes induced by hypersympathetic nerve activity. Experimental physiology, 100, 239-248.

IKRAMUDDIN, S., BLACKSTONE, R. P., BRANCATISANO, A., TOOULI, J., SHAH, S. N., WOLFE, B. M., FUJIOKA, K., MAHER, J. W., SWAIN, J., QUE, F. G., MORTON, J. M., LESLIE, D. B., BRANCATISANO, R., KOW, L., O'ROURKE, R. W., DEVENEY, C., TAKATA, M., MILLER, C. J., KNUDSON, M. B., TWEDEN, K. S., SHIKORA, S. A., SARR, M. G. \& BILLINGTON, C. J. 2014. Effect of reversible intermittent intraabdominal vagal nerve blockade on morbid obesity: the ReCharge randomized clinical trial. 312, 915-922.

JIANG, Y., LI, L., LIU, B., ZHANG, Y., CHEN, Q. \& LI, C. 2014. Vagus nerve stimulation attenuates cerebral ischemia and reperfusion injury via endogenous cholinergic pathway in rat. PLoS One, 9, e102342.

JONES, J. F., WANG, Y. \& JORDAN, D. 1998. Activity of C fibre cardiac vagal efferents in anaesthetized cats and rats. $507,869-880$.

KADISH, A., DYER, A., DAUBERT, J. P., QUIGG, R., ESTES, N. A., ANDERSON, K. P., CALKINS, H., HOCH, D., GOLDBERGER, J., SHALABY, A., SANDERS, W. E., SCHAECHTER, A. \& LEVINE, J. H. 2004. Prophylactic defibrillator implantation in patients with nonischemic dilated cardiomyopathy. The New England journal of medicine, 350, 2151-2158.

KAMPUSCH, S., KANIUSAS, E. \& SZELES, J. C. New approaches in multi-punctual percutaneous stimulation of the auricular vagus nerve. 6th International IEEE/EMBS Conference, 6-8 Nov. 2013 2013 San Diego. 263-266.

KATARE, R. G., ANDO, M., KAKINUMA, Y., ARIKAWA, M., YAMASAKI, F. \& SATO, T. 2010. Differential regulation of TNF receptors by vagal nerve stimulation protects heart against acute ischemic injury. Journal of molecular and cellular cardiology, 49, 234-244.

KATARE, R. G. \& SATO, T. 2007. Functional and molecular basis for vagal nerve stimulation therapy for acute myocardial ischemia and chronic heart failure. Journal of Cardiac Failure, 13, S17.

KAWANO, H., OKADA, R. \& YANO, K. 2003. Histological study on the distribution of autonomic nerves in the human heart. Heart and Vessels, 18, 32-39.

KENT, K. M., SMITH, E. R., REDWOOD, D. R. \& EPSTEIN, S. E. 1973. Electrical stability of acutely ischemic myocardium. Influences of heart rate and vagal stimulation. Circulation, 47, 291-298.

KHODAGHOLY, D., RIVNAY, J., SESSOLO, M., GURFINKEL, M., LELEUX, P., JIMISON, L. H., STAVRINIDOU, E., HERVE, T., SANAUR, S., OWENS, R. M. \& MALLIARAS, G. G. 2013. High transconductance organic electrochemical transistors. Nature communications, 4, 2133.

KHODAPARAST, N., HAYS, S. A., SLOAN, A. M., HULSEY, D. R., RUIZ, A., PANTOJA, M., RENNAKER, R. L., 2ND \& KILGARD, M. P. 2013. Vagus nerve stimulation during rehabilitative training improves forelimb strength following ischemic stroke. Neurobiology of disease, 60, 80-88. 
KIRCHNER, A., BIRKLEIN, F., STEFAN, H. \& HANDWERKER, H. O. 2000. Left vagus nerve stimulation suppresses experimentally induced pain. Neurology, 55, 1167-1171.

KIRCHNER, A., STEFAN, H., BASTIAN, K. \& BIRKLEIN, F. 2006. Vagus nerve stimulation suppresses pain but has limited effects on neurogenic inflammation in humans. European journal of pain (London, England), 10, 449-455.

KOLMAN, B. S., VERRIER, R. L. \& LOWN, B. 1975. The effect of vagus nerve stimulation upon vulnerability of the canine ventricle: role of sympathetic-parasympathetic interactions. Circulation, $52,578-585$.

KONG, S. S., LIU, J. J., HWANG, T. C., YU, X. J., ZHAO, M., ZHAO, M., YUAN, B. X., LU, Y., KANG, Y. M., WANG, B. \& ZANG, W. J. 2012. Optimizing the parameters of vagus nerve stimulation by uniform design in rats with acute myocardial infarction. PLoS One, 7, e42799.

KOX, M., VANEKER, M., VAN DER HOEVEN, J. G., SCHEFFER, G. J., HOEDEMAEKERS, C. W. \& PICKKERS, P. 2012. Effects of vagus nerve stimulation and vagotomy on systemic and pulmonary inflammation in a two-hit model in rats. PLoS One, 7, e34431.

KRAL, J. G., PAEZ, W. \& WOLFE, B. M. 2009. Vagal nerve function in obesity: therapeutic implications. World journal of surgery, 33, 1995-2006.

KREUZER, P. M., LANDGREBE, M., HUSSER, O., RESCH, M., SCHECKLMANN, M., GEISREITER, F., POEPPL, T. B., PRASSER, S. J., HAJAK, G. \& LANGGUTH, B. 2012. Transcutaneous vagus nerve stimulation: retrospective assessment of cardiac safety in a pilot study. Frontiers in psychiatry, 3, 70.

KUCK, K. H., BORDACHAR, P., BORGgReFE, M., BORIANI, G., BURRI, H., LEYVA, F., SCHAUERTE, P., THEUNS, D., THIBAULT, B., DOCUMENT, R., KIRCHHOF, P., HASENFUSS, G., DICKSTEIN, K., LECLERCQ, C., LINDE, C., TAVAZZI, L. \& RUSCHITZKA, F. 2014. New devices in heart failure: an European Heart Rhythm Association report: developed by the European Heart Rhythm Association; endorsed by the Heart Failure Association. Europace: European pacing, arrhythmias, and cardiac electrophysiology : journal of the working groups on cardiac pacing, arrhythmias, and cardiac cellular electrophysiology of the European Society of Cardiology, 16, 109-128.

KUO, J. T., KIM, B. J., HARA, S. A., LEE, C. D., GUTIERREZ, C. A., HOANG, T. Q. \& MENG, E. 2013. Novel flexible Parylene neural probe with 3D sheath structure for enhancing tissue integration. Lab on $a$ chip, 13, 554-561.

KUPARI, M., LINDROOS, M., IIVANAINEN, A. M., HEIKKILA, J. \& TILVIS, R. 1997. Congestive heart failure in old age: prevalence, mechanisms and 4-year prognosis in the Helsinki Ageing Study. 241, 387-394.

LA ROVERE, M. T., BIGGER, J. T., JR., MARCUS, F. I., MORTARA, A. \& SCHWARTZ, P. J. 1998. Baroreflex sensitivity and heart-rate variability in prediction of total cardiac mortality after myocardial infarction. ATRAMI (Autonomic Tone and Reflexes After Myocardial Infarction) Investigators. Lancet, 351, 478-484.

LABINER, D. M. \& AHERN, G. L. 2007. Vagus nerve stimulation therapy in depression and epilepsy: therapeutic parameter settings. Acta neurologica Scandinavica, 115, 23-33.

LADABAUM, U., KOSHY, S. S., WOODS, M. L., HOOPER, F. G., OWYANG, C. \& HASLER, W. L. 1998. Differential symptomatic and electrogastrographic effects of distal and proximal human gastric distension. The American journal of physiology, 275, G418-424. 
LANDAU, A. M., DYVE, S., JAKOBSEN, S., ALSTRUP, A. K. O., GJEDDE, A. \& DOUDET, D. J. 2015. Acute vagal nerve stimulation lowers $\alpha 2$ adrenoceptor occupancy: Possible mechanism of therapeutic action. 8, 702-707.

LATREMOUILLE, C., DUVEAU, D., CHOLLEY, B., ZILBERSTEIN, L., BELBIS, G., BOUGHeNOU, M. F., MELEARD, D., BRUNeVAL, P., ADAM, C., NEUSCHWANDER, A., PERLES, J. C., JANSEN, P. \& CARPENTIER, A. 2015. Animal studies with the Carmat bioprosthetic total artificial heart. 47, e172178.

LEBOVITZ, H. E., LUDVIK, B., YANIV, I., HADDAD, W., SCHWARTZ, T., AVIV, R. \& METACURE INVESTIGATOR, G. 2013. Fasting plasma triglycerides predict the glycaemic response to treatment of type 2 diabetes by gastric electrical stimulation. A novel lipotoxicity paradigm. 30, 687-693.

LEE, S. E., JUN, S. B., LEE, H. J., KIM, J., LEE, S. W., IM, C., SHIN, H. C., CHANG, J. W. \& KIM, S. J. 2012. A flexible depth probe using liquid crystal polymer. 59, 2085-2094.

LEE, S. W., SEO, J. M., HA, S., KIM, E. T., CHUNG, H. \& KIM, S. J. 2009. Development of microelectrode arrays for artificial retinal implants using liquid crystal polymers. Investigative ophthalmology \& visual science, 50, 5859-5866.

LEVINE, Y. A., KOOPMAN, F. A., FALTYS, M., CARAVACA, A., BENDELE, A., ZITNIK, R., VERVOORDELDONK, M. J. \& TAK, P. P. 2014. Neurostimulation of the cholinergic anti-inflammatory pathway ameliorates disease in rat collagen-induced arthritis. PLoS One, 9, e104530.

LEVY, M. N. 1971. Brief reviews: sympathetic-prasympathetic interactions in the heart. Circulation Research, 29, 437-445.

LI, M., ZHENG, C., INAGAKI, M., KAWADA, T., SUNAGAWA, K. \& SUGIMACHI, M. 2005. Chronic vagal stimulation decreased vasopressin secretion and sodium ingestion in heart failure rats after myocardial infarction. Conference proceedings : ... Annual International Conference of the IEEE Engineering in Medicine and Biology Society. IEEE Engineering in Medicine and Biology Society. Annual Conference, 4, 3962-3965.

LI, M., ZHENG, C., SATO, T., KAWADA, T., SUGIMACHI, M. \& SUNAGAWA, K. 2004. Vagal nerve stimulation markedly improves long-term survival after chronic heart failure in rats. Circulation, 109, 120-124.

LI, P., LIU, H., SUN, P., WANG, X., WANG, C., WANG, L. \& WANG, T. 2015. Chronic vagus nerve stimulation attenuates vascular endothelial impairments and reduces the inflammatory profile via inhibition of the NF-kappaB signaling pathway in ovariectomized rats. Experimental gerontology, 74, 43-55.

LI, S., SCHERLAG, B. J., YU, L., SHENG, X., ZHANG, Y., ALI, R., DONG, Y., GHIAS, M. \& PO, S. S. 2009. Low-level vagosympathetic stimulation: a paradox and potential new modality for the treatment of focal atrial fibrillation. Circulation. Arrhythmia and electrophysiology, 2, 645-651.

LI, W. \& OLSHANSKY, B. 2011. Inflammatory cytokines and nitric oxide in heart failure and potential modulation by vagus nerve stimulation. Heart failure reviews, 16, 137-145.

LINDE, C., ABRAHAM, W. T., GOLD, M. R. \& DAUBERT, C. 2010. Cardiac resynchronization therapy in asymptomatic or mildly symptomatic heart failure patients in relation to etiology: results from the REVERSE (REsynchronization reVErses Remodeling in Systolic Left vEntricular Dysfunction) study. 56, 1826-1831. 
LITOVSKY, S. H. \& ANTZELEVITCH, C. 1990. Differences in the electrophysiological response of canine ventricular subendocardium and subepicardium to acetylcholine and isoproterenol. A direct effect of acetylcholine in ventricular myocardium. Circulation research, 67, 615-627.

LIU, X., Demosthenous, A., VANHOESTENBERGHE, A., JIANG, D. \& DONALDSON, N. 2012. Active books: the design of an implantable stimulator that minimizes cable count using integrated circuits very close to electrodes. IEEE transactions on biomedical circuits and systems, 6, 216-227.

LOCKARD, J. S., CONGDON, W. C. \& DUCHARME, L. L. 1990. Feasibility and safety of vagal stimulation in monkey model. Epilepsia, 31, S20-26.

LOEB, G. E. \& PECK, R. A. 1996. Cuff electrodes for chronic stimulation and recording of peripheral nerve activity. Journal of neuroscience methods, 64, 95-103.

LOMAREV, M., DENSLOW, S., NAHAS, Z., CHAE, J. H., GEORGE, M. S. \& BOHNING, D. E. 2002. Vagus nerve stimulation (VNS) synchronized BOLD fMRI suggests that VNS in depressed adults has frequency/dose dependent effects. Journal of Psychiatric Research, 36, 219-227.

LOPEZ, N. E., KRZYZANIAK, M. J., COSTANTINI, T. W., PUTNAM, J., HAGENY, A. M., EliCEIRI, B., COIMBRA, R. \& BANSAL, V. 2012. Vagal nerve stimulation decreases blood-brain barrier disruption after traumatic brain injury. The journal of trauma and acute care surgery, 72, 1562-1566.

MACIEJASZ, P., MARCOL, W., PASNICZEK, R., LEWIN-KOWALIK, J. \& HOFFMANN, K. P. 2013. Automated determination of peripheral nerve stimulation parameters to achieve desired effector response - a procedural routine, preliminary studies and proposal of improvements. Biomedical engineering online, 12, 11.

MALBERT, C.-H. 2013. The brain-gut axis: insights from the obese pig model. Bulletin de l'Academie nationale de medecine, 197, 1683-1694.

MARVIN, H. M. 1927. Digitalis and diuretics in heart failure with regular rhythm, with especial reference to the importance of etiologic classification of heart disease. 3, 521-539.

MASADA, T., ITANO, T., FUJISAWA, M., MIYAMOTO, O., TOKUDA, M., MATSUI, H., NAGAO, S. \& HATASE, O. 1996. Protective effect of vagus nerve stimulation on forebrain ischaemia in gerbil hippocampus. Neuroreport, 7, 446-448.

MATYJA, A., THOR, P. J., SOBOCKI, J., LASKIEWICZ, J., KEKUS, J., TUZ, R., KOCZANOWSKI, J. \& ZARASKA, W. 2004. Effects of vagal pacing on food intake and body mass in pigs. 45, 55-62.

MAYBECK, V., EDGINGTON, R., BONGRAIN, A., WELCH, J. O., SCORSONE, E., BERGONZO, P., JACKMAN, R. B. \& OFFENHAUSSER, A. 2014. Boron-doped nanocrystalline diamond microelectrode arrays monitor cardiac action potentials. Advanced healthcare materials, 3, 283-289.

MCDONAGH, T. A., MORRISON, C. E., LAWRENCE, A., FORD, I., TUNSTALL-PEDOE, H., MCMURRAY, J. J. \& DARGIE, H. J. 1997. Symptomatic and asymptomatic left-ventricular systolic dysfunction in an urban population. Lancet, 350, 829-833.

MCLACHLAN, R. S. 1993. Suppression of interictal spikes and seizures by stimulation of the vagus nerve. Epilepsia, 34, 918-923.

MCMURRAY, J. J., ADAMOPOULOS, S., ANKER, S. D., AURICCHIO, A., BOHM, M., DICKSTEIN, K., FALK, V., FILIPPATOS, G., FONSECA, C., GOMEZ-SANCHEZ, M. A., JAARSMA, T., KOBER, L., LIP, G. Y., MAGGIONI, A. P., PARKHOMENKO, A., PIESKE, B. M., POPESCU, B. A., RONNEVIK, P. K., RUTTEN, F. H., SCHWITTER, J., SEFEROVIC, P., STEPINSKA, J., TRINDADE, P. T., VOORS, A. A., ZANNAD, F., ZEIHER, A. \& GUIDELINES, E. S. C. C. F. P. 2012. ESC Guidelines for the diagnosis and treatment of acute and 
chronic heart failure 2012: The Task Force for the Diagnosis and Treatment of Acute and Chronic Heart Failure 2012 of the European Society of Cardiology. Developed in collaboration with the Heart Failure Association (HFA) of the ESC. European Heart Journal Supplements, 33, 1787-1847.

MCMURRAY, J. J., PACKER, M., DESAI, A. S., GONG, J., LEFKOWITZ, M. P., RIZKALA, A. R., ROULEAU, J. L., SHI, V. C., SOLOMON, S. D., SWEDBERG, K. \& ZILE, M. R. 2014. Angiotensin-neprilysin inhibition versus enalapril in heart failure. 371, 993-1004.

MERRILL, D. R., BIKSON, D. \& JEFFERYS, D. G. R. 2005. Electrical stimulation of excitable tissue: design of efficacious and safe protocols. Journal of neuroscience methods, 141, 171-198.

MEYER, R. D., COGAN, S. F., NGUYEN, T. H. \& RAUH, R. D. 2001. Electrodeposited iridium oxide for neural stimulation and recording electrodes. IEEE transactions on neural systems and rehabilitation engineering : a publication of the IEEE Engineering in Medicine and Biology Society, 9, 2-11.

MIHAYLOVA, S., KILLIAN, A., MAYER, K., PULLAMSETTI, S. S., SCHERMULY, R. \& ROSENGARTEN, B. 2012. Effects of anti-inflammatory vagus nerve stimulation on the cerebral microcirculation in endotoxinemic rats. Journal of neuroinflammation, 9, 183.

MILBY, A. H., HALPERN, C. H. \& BALTUCH, G. H. 2008. Vagus nerve stimulation for epilepsy and depression. Neurotherapeutics: the journal of the American Society for Experimental NeuroTherapeutics, 5, 75-85.

MIRAS, M., SERRANO, M., DURAN, C., VALINO, C. \& CANTON, S. 2015. Early experience with customized, meal-triggered gastric electrical stimulation in obese patients. 25, 174-9.

MIZRAHI, M., BEN YA'ACOV, A. \& ILAN, Y. 2012. Gastric stimulation for weight loss. World journal of gastroenterology: WJG, 18, 2309-2319.

MORGAN, S., SMITH, H., SIMPSON, I., LIDDIARD, G. S., RAPHAEL, H., PICKERING, R. M. \& MANT, D. 1999. Prevalence and clinical characteristics of left ventricular dysfunction among elderly patients in general practice setting: cross sectional survey. 318, 368-372.

MORTARA, A., LA ROVERE, M. T., PINNA, G. D., PRPA, A., MAESTRI, R., FEBO, O., POZZOLI, M., OPASICH, C. \& TAVAZZI, L. 1997. Arterial baroreflex modulation of heart rate in chronic heart failure: clinical and hemodynamic correlates and prognostic implications. Circulation, 96, 3450-3458.

MOSS, A. J., HALL, W. J., CANNOM, D. S., KLEIN, H., BROWN, M. W., DAUBERT, J. P., ESTES, N. A., 3RD, FOSTER, E., GREENBERG, H., HIGGINS, S. L., PFEFFER, M. A., SOLOMON, S. D., WILBER, D. \& ZAREBA, W. 2009. Cardiac-resynchronization therapy for the prevention of heart-failure events. 361, 132938.

MOSTERD, A., HOES, A. W., DE BRUYNE, M. C., DECKERS, J. W., LINKER, D. T., HOFMAN, A. \& GROBBEE, D. E. 1999. Prevalence of heart failure and left ventricular dysfunction in the general population; The Rotterdam Study. 20, 447-455.

MU, Q., BOHNING, D. E., NAHAS, Z., WALKER, J., ANDERSON, B., JOHNSON, K., DENSLOW, S., LOMAREV, M., MOGHADAM, P., CHAE, J. H. \& GEORGE, M. S. 2004. Acute vagus nerve stimulation using different pulse widths produces varying brain effects. Biological Psychiatry, 55, 816-825.

MURAKAWA, Y., YAMASHITA, T., AJIKI, K., HAYAMI, N., OMATA, M. \& NAGAI, R. 2003. Effect of cervical vagal nerve stimulation on defibrillation energy: a possible adjunct to efficient defibrillation. Japanese heart journal, 44, 91-100.

MURPHY, N. F., SIMPSON, C. R., MCALISTER, F. A., STEWART, S., MACINTYRE, K., KIRKPATRICK, M., CHALMERS, J., REDPATH, A., CAPEWELL, S. \& MCMURRAY, J. J. 2004. National survey of the 
prevalence, incidence, primary care burden, and treatment of heart failure in Scotland. Heart, 90, 1129-1136.

MUSA, S., RAND, D. R., COTT, D. J., LOO, J., BARTIC, C., EBERLE, W., NUTTIN, B. \& BORGHS, G. 2012. Bottom-up SiO2 embedded carbon nanotube electrodes with superior performance for integration in implantable neural microsystems. ACS Nano, 6, 4615-4628.

MYERS, R. W., PEARLMAN, A. S., HYMAN, R. M., GOLDSTEIN, R. A., KENT, K. M., GOLDSTEIN, R. E. \& EPSTEIN, S. E. 1974. Beneficial effects of vagal stimulation and bradycardia during experimental acute myocardial ischemia. Circulation, 49, 943-947.

NAHAS, Z., MARANGELL, L. B., HUSAIN, M. M., RUSH, A. J., SACKEIM, H. A., LISANBY, S. H., MARTINEZ, J. M. \& GEORGE, M. S. 2005. Two-year outcome of vagus nerve stimulation (VNS) for treatment of major depressive episodes. 66, 1097-1104.

NEREN, D., JOHNSON, M. D., LEGON, W., BACHOUR, S. P., LING, G. \& DIVANI, A. A. 2015. Vagus nerve stimulation and other neuromodulation methods for treatment of traumatic brain injury. Neurocritical care, 24, 308-319.

NG, G. A., BRACK, K. E., PATEL, V. H. \& COOTE, J. H. 2007. Autonomic modulation of electrical restitution, alternans and ventricular fibrillation initiation in the isolated heart. $73,750-760$.

NIELSEN, K. R., SEVCENCU, C. \& STRUIJK, J. 2008. Vagus nerve activity based prediction of epileptic seizures in rats. Biomedizinische Technik, 53, 13-15.

NIKOLIĆ, Z. M., POPOVIĆ, D. B., STEIN, R. B. \& KENWELL, Z. 1994. Instrumentation for ENG and EMG recordings in FES systems. IEEE transactions on bio-medical engineering, 41, 703-706.

OGAWA, M., ZHOU, S., TAN, A. Y., SONG, J., GHOLMIEH, G., FISHBEIN, M. C., LUO, H., SIEGEL, R. J., KARAGUEUZIAN, H. S., CHEN, L. S., LIN, S. F. \& CHEN, P. S. 2007. Left stellate ganglion and vagal nerve activity and cardiac arrhythmias in ambulatory dogs with pacing-induced congestive heart failure. Journal of the American College of Cardiology, 50, 335-343.

ORDELMAN, S. C. M. A. 2012. Sensing and stimulation of the vagus nerve for artificial cardiac control. University of Twente, Netherlands.

ORDELMAN, S. C. M. A., KORNET, L., CORNELUSSEN, R., BUSCHMAN, H. P. J. \& VELTINK, P. H. 2013. Selectivity for specific cardiovascular effects of vagal nerve stimulation with a multi-contact electrode cuff. 21, 32-36.

PARAMESHWAR, J., SHACKELL, M. M., RICHARDSON, A., POOLE-WILSON, P. A. \& SUTTON, G. C. 1992. Prevalence of heart failure in three general practices in north west London. 42, 287-9.

PARATI, G. \& ESLER, M. 2012. The human sympathetic nervous system: its relevance in hypertension and heart failure. European heart journal, 33, 1058-1066.

PARDO, J. V., SHEIKH, S. A., KUSKOWSKI, M. A., SURERUS-JOHNSON, C., HAGEN, M. C., LEE, J. T., RITTBERG, B. R. \& ADSON, D. E. 2007. Weight loss during chronic, cervical vagus nerve stimulation in depressed patients with obesity: an observation. International journal of obesity, 31, 1756-1759.

PATRICK, E., SANKAR, V., ROWE, W., SANCHEZ, J. C. \& NISHIDA, T. 2010. An implantable integrated low-power amplifier-microelectrode array for Brain-Machine Interfaces. Conference proceedings :... Annual International Conference of the IEEE Engineering in Medicine and Biology Society. IEEE Engineering in Medicine and Biology Society. Conference, 2010, 1816-1819. 
PECLIN, P. \& ROZMAN, J. 2014. Alternative paradigm of selective vagus nerve stimulation tested on an isolated porcine vagus nerve. The Scientific World Journal, 2014, 310283.

PELLISSIER, S., SINNIGER, V., KIBLEUR, A., HOFFMAN, D., VERCUEIL, L., DAVID, O. \& BONAZ, B. 2014. Long term effects of low frequency $(10 \mathrm{hz})$ vagus nerve stimulation on EEG and heart rate variability in Crohn's disease: a case report. Brain Stimulation, 7, 1-3.

PENA, D. F., CHILDS, J. E., WILLETT, S., VITAL, A., MCINTYRE, C. K. \& KROENER, S. 2014. Vagus nerve stimulation enhances extinction of conditioned fear and modulates plasticity in the pathway from the ventromedial prefrontal cortex to the amygdala. Frontiers in behavioral neuroscience, 8, 327.

PENRY, J. K. \& DEAN, J. C. 1990. Prevention of intractable partial seizures by intermittent vagal stimulation in humans: preliminary results. Epilepsia, 31, S40-43.

PLACHTA, D. T., GIERTHMUEHLEN, M., COTA, O., ESPINOSA, N., BOESER, F., HERRERA, T. C., STIEGLITZ, T. \& ZENTNER, J. 2014. Blood pressure control with selective vagal nerve stimulation and minimal side effects. Journal of neural engineering, 11, 036011.

PLACHTA, D. T. T., ESPINOSA, N., GIERTHMUEHLEN, M., COTA, O., HERRERA, T. C. \& STIEGLITZ, T. 2012. Detection of baroreceptor activity in rat vagal nerve recording using a multi-channel cuffelectrode and real-time coherent averaging. 3416-3419.

PREMCHAND, R. K., SHARMA, K., MITTAL, S., MONTEIRO, R., DIXIT, S., LIBBUS, I., DICARLO, L. A., ARDELL, J. L., RECTOR, T. S., AMURTHUR, B., KENKNIGHT, B. H. \& ANAND, I. S. 2014. Autonomic regulation therapy via left or right cervical vagus nerve stimulation in patients with chronic heart failure: results of the ANTHEM-HF trial. Journal of Cardiac Failure, 20, 808-816.

PREMCHAND, R. K., SHARMA, K., MITTAL, S., MONTEIRO, R., LIBBUS, I., DICARLO, L., ARDELL, J. L., RECTOR, T. S., AMURTHUR, B., KENKNIGHT, B. H. \& ANAND, I. S. 2015. ENCORE: Extension of the ANTHEM-HF study evaluating autonomic regulation therapy in reduced ejection fraction heart failure. $21,940$.

PRYSTOWSKY, E. N., JACKMAN, W. M., RINKENBERGER, R. L., HEGER, J. J. \& ZIPES, D. P. 1981. Effect of autonomic blockade on ventricular refractoriness and atrioventricular nodal conduction in humans. Evidence supporting a direct cholinergic action on ventricular muscle refractoriness. Circulation research, 49, 511-518.

QING, K., WARD, M. \& IRAZOQUI, P. 2015. Burst-modulated waveforms optimize electrical stimuli for charge efficiency and fiber selectivity. IEEE transactions on neural systems and rehabilitation engineering : a publication of the IEEE Engineering in Medicine and Biology Society, 23, 936-945.

RANDALL, W. C. \& ARMOUR, J. A. 1974. Regional vagosympathetic control of the heart. The American Journal of Physiology, 227, 444-452.

RICHARDS, W. 2009. Comment on: Selection of electrical algorithms to treat obesity with intermittent vagal block using an implantable medical device. Surgery for Obesity and Related Diseases, 5, 229230.

RIEGER, R. \& TAYLOR, J. 2013. A switched-capacitor front-end for velocity-selective ENG recording. IEEE Transactions on Biomedical Circuits and Systems, 7, 480-488.

RIEGER, R., TAYLOR, J., COMI, E., DONALDSON, N., RUSSOLD, M., MAHONY, C. M. O., MCLAUGHLIN, J. A., MCADAMS, E., DEMOSTHENOUS, A. \& JARVIS, J. C. 2004. Experimental determination of compound action potential direction and propagation velocity from multi-electrode nerve cuffs. Medical engineering \& physics, 26, 531-534. 
RODGER, D. C., FONG, A. J., LI, W., AMERI, H., AHUJA, A. K., GUTIERREZ, C., LAVROV, I., ZHONG, H., MENON, P. R., MENG, E., BURDICK, J. W., ROY, R. R., EDGERTON, V. R., WEILAND, J. D., HUMAYUN, M. S. \& TAI, Y.-C. 2008. Flexible parylene-based multielectrode array technology for high-density neural stimulation and recording. Sensors and Actuators B: Chemical, 132, 449-460.

RODRIGUEZ, F. J., CEBALlOS, D., SCHUTtLER, M., VALERO, A., VALDERRAMA, E., STIEGLITZ, T. \& NAVARRO, X. 2000. Polyimide cuff electrodes for peripheral nerve stimulation. Journal of neuroscience methods, 98, 105-118.

ROMERO UGALDE, H. M., OJEDA, D., LE ROLLE, V., ROSSEL, O., BONNET, J.-L., KARAM, N., HAGÈGE, A., MABO, P., CARRAULT, G. \& HERNANDEZ, A. I. 2015. Model-based design of control modules for neuromodulation devices. IEEE Trans Biomed Eng, (in press).

ROSLIN, M. \& KURIAN, M. 2001. The use of electrical stimulation of the vagus nerve to treat morbid obesity. Epilepsy \& Behavior, 2, S11-S16.

ROUSSELET, L., LE ROLLE, V., OJEDA, D., GUIRAUD, D., HAGÈGE, A., BEL, A., BONNET, J.-L., MABO, P., CARRAULT, G. \& HERNANDEZ, A. I. 2014. Influence of vagus nerve stimulation parameters on chronotropism and inotropism in heart failure. IEEE Engineering in Medicine and Biology Society, 526-529.

ROZMAN, J. \& RIBARIČ, S. 2007. Selective recording of electroneurograms from the left vagus nerve of a dog during stimulation of cardiovascular or respiratory systems. The Chinese journal of physiology, 50, 240-250.

RUBEHN, B. \& STIEGLITZ, T. 2010. In vitro evaluation of the long-term stability of polyimide as a material for neural implants. Biomaterials, 31, 3449-3458.

RUSH, A. J., GEORGE, M. S., SACKEIM, H. A., MARANGELL, L. B., HUSAIN, M. M., GILLER, C., NAHAS, Z., HAINES, S., SIMPSON, R. K., JR. \& GOODMAN, R. 2000. Vagus nerve stimulation (VNS) for treatmentresistant depressions: a multicenter study. Biological Psychiatry, 47, 276-286.

RUSH, A. J., MARANGELL, L. B., SACKEIM, H. A., GEORGE, M. S., BRANNAN, S. K., DAVIS, S. M., HOWLAND, R., KLING, M. A., RITTBERG, B. R., BURKE, W. J., RAPAPORT, M. H., ZAJECKA, J., NIERENBERG, A. A., HUSAIN, M. M., GINSBERG, D. \& COOKE, R. G. 2005a. Vagus nerve stimulation for treatment-resistant depression: a randomized, controlled acute phase trial. 58, 347-354.

RUSH, A. J., SACKEIM, H. A., MARANGELL, L. B., GEORGE, M. S., BRANNAN, S. K., DAVIS, S. M., LAVORI, P., HOWLAND, R., KLING, M. A., RITTBERG, B., CARPENTER, L., NINAN, P., MORENO, F., SCHWARTZ, T., CONWAY, C., BURKE, M. \& BARRY, J. J. 2005b. Effects of 12 months of vagus nerve stimulation in treatment-resistant depression: a naturalistic study. 58, 355-363.

SABBAH, H. N., ILSAR, I., ZARETSKY, A., RASTOGI, S., WANG, M. \& GUPTA, R. C. 2011. Vagus nerve stimulation in experimental heart failure. Heart failure reviews, 16, 171-178.

SABBAH, H. N., IMAI, M., ZARETSKY, A., RASTOGI, S., WANG, M., JIANG, A. \& ZACA, V. 2007. Therapy with vagus nerve electrical stimulation combined with beta-blockade improves left ventricular systolic function in dogs with heart failure beyond that seen with beta- blockade alone. European Journal of Heart Failure, 6, 114.

SACKEIM, H. A., RUSH, A. J., GEORGE, M. S., MARANGELL, L. B., HUSAIN, M. M., NAHAS, Z., JOHNSON, C. R., SEIDMAN, S., GILLER, C., HAINES, S., SIMPSON, R. K., JR. \& GOODMAN, R. R. 2001. Vagus nerve stimulation (VNS) for treatment-resistant depression: efficacy, side effects, and predictors of outcome. Neuropsychopharmacology, 25, 713-728. 
SANMiguel, C., CONKLIN, J., CUNNEEN, S., BARNETT, P., PHILliPS, E., KIPNES, M., PILCHER, J. \& SOFFER, E. 2009. Gastric electrical stimulation with the TANTALUS System in obese type 2 diabetes patients: effect on weight and glycemic control. 3, 964-970.

SARR, M. G., BILLINGTON, C. J., BRANCATISANO, R., BRANCATISANO, A., TOOULI, J., KOW, L., NGUYEN, N. T., BLACKSTONE, R., MAHER, J. W., SHIKORA, S., REEDS, D. N., EAGON, J. C., WOLFE, B. M., O'ROURKE, R. W., FUJIOKA, K., TAKATA, M., SWAIN, J. M., MORTON, J. M., IKRAMUDDIN, S., SCHWEITZER, M., CHAND, B., ROSENTHAL, R. \& GROUP, E. S. 2012. The EMPOWER study: randomized, prospective, double-blind, multicenter trial of vagal blockade to induce weight loss in morbid obesity. Obesity Surgery, 22, 1771-1782.

SAUTER-STARACE, F., BIBARI, O., BERGER, F., CAILLAT, P. \& BENABID, A. L. ECoG recordings of a nonhuman primate using carbon nanotubes electrodes on a flexible polyimide implant. 4th International IEEE/EMBS Conference on Neural Engineering, April 29 2009-May 220092009 Antalya. 112-115.

SCHLAEPFER, T. E., FRICK, C., ZOBEL, A., MAIER, W., HEUSER, I., BAJBOUJ, M., O'KEANE, V., CORCORAN, C., ADOLFSSON, R., TRIMBLE, M., RAU, H., HOFF, H. J., PADBERG, F., MULLERSIECHENEDER, F., AUDENAERT, K., VAN DEN, A. D., STANGA, Z. \& HASDEMIR, M. 2008. Vagus nerve stimulation for depression: efficacy and safety in a European study. Psychological Medicine, 38, 651661.

SCHWARTZ, P. J. \& DE FERRARI, G. M. 2009. Vagal stimulation for heart failure: background and first in-man study. Heart Rhythm, 6, S76-81.

SCHWARTZ, P. J., DE FERRARI, G. M., SANZO, A., LANDOLINA, M., RORDORF, R., RAINERI, C., CAMPANA, C., REVERA, M., AJMONE-MARSAN, N., TAVAZZI, L. \& ODERO, A. 2008. Long term vagal stimulation in patients with advanced heart failure: first experience in man. European Journal of Heart Failure, 10, 884-891.

SEKI, A., GREEN, H. R., LEE, T. D., HONG, L., TAN, J., VINTERS, H. V., CHEN, P. S. \& FISHBEIN, M. C. 2014. Sympathetic nerve fibers in human cervical and thoracic vagus nerves. Heart Rhythm, 11, 1411-1417.

SHEN, M. J., SHINOHARA, T., PARK, H. W., FRICK, K., ICE, D. S., CHOI, E. K., HAN, S., MARUYAMA, M., SHARMA, R., SHEN, C., FISHBEIN, M. C., CHEN, L. S., LOPSHIRE, J. C., ZIPES, D. P., LIN, S. F. \& CHEN, P. S. 2011. Continuous low-level vagus nerve stimulation reduces stellate ganglion nerve activity and paroxysmal atrial tachyarrhythmias in ambulatory canines. Circulation, 123, 2204-2212.

SHIKORA, S., TOOULI, J., HERRERA, M. F., KULSENG, B., ZULEWSKI, H., BRANCATISANO, R., KOW, L., PANTOJA, J. P., JOHNSEN, G., BRANCATISANO, A., TWEDEN, K. S., KNUDSON, M. B. \& BILLINGTON, C. J. 2013. Vagal blocking improves glycemic control and elevated blood pressure in obese subjects with type 2 diabetes mellitus. 2013, 245683.

SHINLAPAWITTAYATORN, K., CHINDA DVM, K., PALEE, S., SURINKAEW, S., THUNSIRI, K., WEERATEERANGKUL, P., CHATTIPAKORN, S., KEN KNIGHT, B. H. \& CHATTIPAKORN, N. 2013. Lowamplitude, left vagus nerve stimulation significantly attenuates ventricular dysfunction and infarct size through prevention of mitochondrial dysfunction during acute ischemia-reperfusion injury. Heart Rhythm: the official journal of the Heart Rhythm Society, 10, 1700-1707.

SNEDDON, J. F., BASHIR, Y. \& WARD, D. E. 1993. Vagal stimulation after myocardial infarction: Accentuating the positive. Journal of the American College of Cardiology, 22, 1335-1337. 
SOO HYUN, L., JUNG HWAN, J., YOUN MEE, C. \& JI YOON, K. Fabrication and characteristics of the implantable and flexible nerve cuff electrode for neural interfaces. 4th International IEEE/EMBS Conference on Neural Engineering, April 29 2009-May 220092009 Antalya. 80-83.

SOULIER, F., LERAT, J. B., GOUYET, L., BERNARD, S. \& CATHEBRAS, G. A neural stimulator output stage for dodecapolar electrodes. IEEE Computer Society Annual Symposium on VLSI, 7-9 April 20082008 Montpellier. 487-490.

SPERLING, W., REULBACH, U., BLEICH, S., PADBERG, F., KORNHUBER, J. \& MUECK-WEYMANN, M. 2010. Cardiac effects of vagus nerve stimulation in patients with major depression. Pharmacopsychiatry, 43, 7-11.

STAVRAKIS, S., HUMPHREY, M. B., SCHERLAG, B. J., HU, Y., JACKMAN, W. M., NAKAGAWA, H., LOCKWOOD, D., LAZZARA, R. \& PO, S. S. 2015. Low-level transcutaneous electrical vagus nerve stimulation suppresses atrial fibrillation. Journal of the American College of Cardiology, 65, 867-875.

STAVRAKIS, S., SCHERLAG, B. J., FAN, Y., LIU, Y., MAO, J., VARMA, V., LAZZARA, R. \& PO, S. S. 2013. Inhibition of atrial fibrillation by low-level vagus nerve stimulation: the role of the nitric oxide signaling pathway. Journal of interventional cardiac electrophysiology : an international journal of arrhythmias and pacing, 36, 199-208.

STEIN, R. B., CHARLES, D., DAVIS, L., JHAMANDAS, J., MANNARD, A. \& NICHOLS, T. R. 1975. Principles underlying new methods for chronic neural recording. The Canadian journal of neurological sciences. Le journal canadien des sciences neurologiques, 2, 235-244.

STIEGLITZ, T., SCHUETTER, M. \& KOCH, K. P. 2005. Implantable biomedical microsystems for neural prostheses. IEEE Engineering in Medicine and Biology Magazine, 24, 58-65.

SUN, Z., BAKER, W., HIRAKI, T. \& GREENBERG, J. H. 2012. The effect of right vagus nerve stimulation on focal cerebral ischemia: an experimental study in the rat. Brain stimulation, 5, 1-10.

SUNAGAWA, K. 2005. Electrical vagal stimulation of the heart markedly improves long-term survival in rats with chronic heart failure. Journal of Cardiac Failure, 11, S260.

SWEDBERG, K., KOMAJDA, M., BOHM, M., BORER, J. S., FORD, I., DUBOST-BRAMA, A., LEREBOURS, G. \& TAVAZZI, L. 2010. Ivabradine and outcomes in chronic heart failure (SHIFT): a randomised placebo-controlled study. Lancet, 376, 875-885.

TANG, A. S., WELLS, G. A., TALAJIC, M., ARNOLD, M. O., SHELDON, R., CONNOLLY, S., HOHNLOSER, S. H., NICHOL, G., BIRNIE, D. H., SAPP, J. L., YEE, R., HEALEY, J. S. \& ROULEAU, J. L. 2010. Cardiacresynchronization therapy for mild-to-moderate heart failure. 363, 2385-2395.

TANG, Y., WODLINGER, B. \& DURAND, D. M. 2014. Bayesian spatial filters for source signal extraction: A study in the peripheral nerve. IEEE Transactions on Neural Systems and Rehabilitation Engineering, 22, 302-311.

TARZIA, V., BURATTO, E., GALLO, M., BORTOLUSSI, G., BEJKO, J., DAL LIN, C., TORREGROSSA, G., BIANCO, R., BOTTIO, T. \& GEROSA, G. 2014. Surgical implantation of the CardioWest total artificial heart. 3, 624-625.

TECHER, J. D., BERNARD, S., BERTRAND, Y., CATHÉBRAS, G. \& GUIRAUD, D. 2004. An implantable ASIC for neural stimulation. Biomedical Circuits and Systems. Singapur.

TESFAYESUS, W. \& DURAND, D. M. Recovery of fascicular signals from whole nerve recordings - A simulation study. Conference Proceedings. 2nd International IEEE EMBS Conference on Neural Engineering, 16-19 March 20052005 Arlington. 175-178. 
TESFAYESUS, W. \& DURAND, D. M. 2007. Blind source separation of peripheral nerve recordings. Journal of neural engineering, 4, S157-167.

TESFAYESUS, W., YOO, P., MOFFITT, M. \& DURAND, D. M. 2004. Blind source separation of nerve cuff recordings. Proceedings of the 25th Annual International Conference of the IEEE, 1, 95-98.

TILLER, D., RUSS, M., GREISER, K. H., NUDING, S., EBELT, H., KLUTTIG, A., KORS, J. A., THIERY, J., BRUEGEL, M., HAERTING, J. \& WERDAN, K. 2013. Prevalence of symptomatic heart failure with reduced and with normal ejection fraction in an elderly general population-the CARLA study. PLoS One, 8, e59225.

TOSATO, M., YOSHIDA, K., TOFT, E., NEKRASAS, V. \& STRUIJK, J. J. 2006. Closed-loop control of the heart rate by electrical stimulation of the vagus nerve. Medical \& biological engineering \& computing, 44, 161-169.

TYLER, D. J. \& DURAND, D. M. 2002. Functionally selective peripheral nerve stimulation with a flat interface nerve electrode. IEEE transactions on neural systems and rehabilitation engineering : a publication of the IEEE Engineering in Medicine and Biology Society, 10, 294-303.

UEMURA, K., ZHENG, C., LI, M., KAWADA, T. \& SUGIMACHI, M. 2010. Early short-term vagal nerve stimulation attenuates cardiac remodeling after reperfused myocardial infarction. Journal of cardiac failure, 16, 689-699.

UGALDE, H. R., LE ROLLE, V., BEL, A., BONNET, J. L., ANDREU, D., MABO, P., CARRAULT, G. \& HERNANDEZ, A. I. 2014. On-off closed-loop control of vagus nerve stimulation for the adaptation of heart rate. Engineering in Medicine and Biology Society (EMBC), 2014 36th Annual International Conference of the IEEE, 6262-6265.

UITTERDIJK, A., YETGIN, T., TE LINTEL HEKKERT, M., SNEEP, S., KRABBENDAM-PETERS, I., VAN BEUSEKOM, H. M., FISCHER, T. M., CORNELUSSEN, R. N., MANINTVELD, O. C., MERKUS, D. \& DUNCKER, D. J. 2015. Vagal nerve stimulation started just prior to reperfusion limits infarct size and no-reflow. Basic research in cardiology, 110, 508.

ULPHANI, J. S., CAIN, J. H., INDERYAS, F., GORDON, D., GIKAS, P. V., SHADE, G., MAYOR, D., ARORA, R., KADISH, A. H. \& GOLDBERGER, J. J. 2010. Quantitative analysis of parasympathetic innervation of the porcine heart. Heart Rhythm : the official journal of the Heart Rhythm Society, 7, 1113-1119.

VAes, B., Rezzoug, N., PAsquet, A., WAllemaco, P., VAN POtTelbergh, G., Mathel, C., VANOVERSCHELDE, J. L. \& DEGRYSE, J. 2012. The prevalence of cardiac dysfunction and the correlation with poor functioning among the very elderly. 155, 134-143.

VAL-LAILleT, D., BIRABEN, A., RANDUINEAU, G. \& MALBERT, C. H. 2010a. Chronic vagus nerve stimulation decreased weight gain, food consumption and sweet craving in adult obese minipigs. Appetite, 55, 245-252.

VAL-LAILLET, D., BLAT, S., LOUVEAU, I. \& MALBERT, C. H. 2010b. A computed tomography scan application to evaluate adiposity in a minipig model of human obesity. The British journal of nutrition, 104, 1719-1728.

VAN DEN HONERT, C. \& MORTIMER, J. T. 1981. A technique for collision block of peripheral nerve: single stimulus analysis. 28, 373-378.

VAN WESTERLOO, D. J., GIEBELEN, I. A., MEIJERS, J. C. M., DAALHUISEN, J., DE VOS, A. F., LEVI, M. \& VAN DER POLL, T. 2006. Vagus nerve stimulation inhibits activation of coagulation and fibrinolysis during endotoxemia in rats. 4, 1997-2002. 
VANOLI, E., DE FERRARI, G. M., STRAMBA-BADIALE, M., HULL, S. S., FOREMAN, R. D. \& SCHWARTZ, P. J. 1991. Vagal stimulation and prevention of sudden death in conscious dogs with a healed myocardial infarction. Circulation Research, 68, 1471-1481.

VERLINDEN, T. J., RIJKERS, K., HOOGLAND, G. \& HERRLER, A. 2016. Morphology of the human cervical vagus nerve: implications for vagus nerve stimulation treatment. Acta neurologica Scandinavica, $133,173-182$.

VONCK, K., RAEDT, R., NAULAERTS, J., DE VOGELAERE, F., THIERY, E., VAN ROOST, D., ALDENKAMP, B., MIATTON, M. \& BOON, P. 2014. Vagus nerve stimulation...25 years later! What do we know about the effects on cognition? Neuroscience and biobehavioral reviews, 45, 63-71.

VUCKOVIC, A., TOSATO, M. \& STRUIJK, J. J. 2008. A comparative study of three techniques for diameter selective fiber activation in the vagal nerve: anodal block, depolarizing prepulses and slowly rising pulses. 5, 275-286.

WAATAJA, J. J., TWEDEN, K. S. \& HONDA, C. N. 2011. Effects of high-frequency alternating current on axonal conduction through the vagus nerve. Journal of neural engineering, 8, 056013.

WANG, Z., YU, L., CHEN, M., WANG, S. \& JIANG, H. 2014a. Transcutaneous electrical stimulation of auricular branch of vagus nerve: A noninvasive therapeutic approach for post-ischemic heart failure. International Journal of Cardiology, 177, 676-677.

WANG, Z., YU, L., HUANG, B., WANG, S., LIAO, K., SAREN, G., ZHOU, X. \& JIANG, H. 2015a. Low-level transcutaneous electrical stimulation of the auricular branch of vagus nerve ameliorates left ventricular remodeling and dysfunction by downregulation of matrix metalloproteinase 9 and transforming growth factor beta1. Journal of cardiovascular pharmacology, 65, 342-348.

WANG, Z., YU, L., WANG, S., HUANG, B., LIAO, K., SAREN, G., TAN, T. \& JIANG, H. 2014b. Chronic intermittent low-level transcutaneous electrical stimulation of auricular branch of vagus nerve improves left ventricular remodeling in conscious dogs with healed myocardial infarction. Circulation. Heart failure, 7, 1014-1021.

WANG, Z., ZHOU, X., SHENG, X., YU, L. \& JIANG, H. 2015b. Noninvasive vagal nerve stimulation for heart failure: Was it practical or just a stunt? International journal of cardiology, 187, 637-638.

WANG, Z., ZHOU, X., SHENG, X., YU, L. \& JIANG, H. 2015c. Unilateral low-level transcutaneous electrical vagus nerve stimulation: A novel noninvasive treatment for myocardial infarction. International journal of cardiology, 190, 9-10.

WANINGER, M. S., BOURLAND, J. D., GEDDES, L. A., SCHOENLEIN, W. E., GRABER, G., WEIRICH, W. E. \& WODICKA, G. R. 2000. Electrophysiological control of ventricular rate during atrial fibrillation. Pacing and Clinical Electrophysiology, 23, 1239-1244.

WEILAND, J. D., ANDERSON, D. J. \& HUMAYUN, M. S. 2002. In vitro electrical properties for iridium oxide versus titanium nitride stimulating electrodes. IEEE transactions on bio-medical engineering, 49, 1574-1579.

WODLINGER, B. \& DURAND, D. M. 2009. Localization and recovery of peripheral neural sources with beamforming algorithms. IEEE transactions on neural systems and rehabilitation engineering : a publication of the IEEE Engineering in Medicine and Biology Society, 17, 461-468.

WOODBURY, D. M. \& WOODBURY, J. W. 1990. Effects of vagal stimulation on experimentally induced seizures in rats. Epilepsia, 31, S7-19. 
WU, W. \& LU, Z. 2011. Loss of anti-arrhythmic effect of vagal nerve stimulation on ischemia-induced ventricular tachyarrhythmia in aged rats. The Tohoku journal of experimental medicine, 223, 27-33.

YAMAKAWA, K., MATSUMOTO, N., IMAMURA, Y., MUROYA, T., YAMADA, T., NAKAGAWA, J., SHIMAZAKI, J., OGURA, H., KUWAGATA, Y. \& SHIMAZU, T. 2013. Electrical vagus nerve stimulation attenuates systemic inflammation and improves survival in a rat heatstroke model. PloS One, 8, e56728-e56728.

YAMAKAWA, K., RAJENDRAN, P. S., TAKAMIYA, T., YAGASHITA, D., SO, E. L., MAHAJAN, A., SHIVKUMAR, K. \& VASEGHI, M. 2015. Vagal nerve stimulation activates vagal afferent fibers that reduce cardiac efferent parasympathetic effects. American Journal of Physiology. Heart and Circulatory Physiology, 309, H1579-1590.

YOSHIDA, K. \& HORCH, K. 1993. Selective stimulation of peripheral nerve fibers using dual intrafascicular electrodes. IEEE transactions on bio-medical engineering, 40, 492-494.

YOSHIDA, K. \& HORCH, K. 1996. Closed-loop control of ankle position using muscle afferent feedback with functional neuromuscular stimulation. Biomedical Engineering, IEEE Transactions on, 43, 167176.

YU, L., SCHERLAG, B. J., LI, S., FAN, Y., DYER, J., MALE, S., VARMA, V., SHA, Y., STAVRAKIS, S. \& PO, S. S. 2013. Low-level transcutaneous electrical stimulation of the auricular branch of the vagus nerve: a noninvasive approach to treat the initial phase of atrial fibrillation. Heart Rhythm : the official journal of the Heart Rhythm Society, 10, 428-435.

YU, L., SCHERLAG, B. J., LI, S., SHENG, X., LU, Z., NAKAGAWA, H., ZHANG, Y., JACKMAN, W. M., LAZZARA, R., JIANG, H. \& PO, S. S. 2011. Low-level vagosympathetic nerve stimulation inhibits atrial fibrillation inducibility: direct evidence by neural recordings from intrinsic cardiac ganglia. Journal of cardiovascular electrophysiology, 22, 455-463.

ZABARA, J. 1985. Peripheral control of hypersynchronous discharge in epilepsy. Electroencephalography and Clinical Neurophysiology, 61, S162.

ZAMOTRINSKY, A. V., KONDRATIEV, B. \& DE JONG, J. W. 2001. Vagal neurostimulation in patients with coronary artery disease. Autonomic neuroscience : basic \& clinical, 88, 109-116.

ZANCHETTI, A., WANG, S. C. \& MORUZZI, G. 1952. The effect of vagal afferent stimulation on the EEG pattern of the cat. 4, 357-361.

ZANNAD, F., DE FERRARI, G. M., TUINENBURG, A. E., WRIGHT, D., BRUGADA, J., BUTTER, C., KLEIN, H., STOLEN, C., MEYER, S., STEIN, K. M., RAMUZAT, A., SCHUBERT, B., DAUM, D., NEUZIL, P., BOTMAN, C., CASTEL, M. A., D'ONOFRIO, A., SOLOMON, S. D., WOLD, N. \& RUBLE, S. B. 2015. Chronic vagal stimulation for the treatment of low ejection fraction heart failure: results of the NEural Cardiac TherApy foR Heart Failure (NECTAR-HF) randomized controlled trial. European Heart Journal, 36, 425-433.

ZARIFFA, J. \& POPOVIC, M. R. 2009. Localization of active pathways in peripheral nerves: A simulation study. Neural Systems and Rehabilitation Engineering, IEEE Transactions on, 17, 53-62.

ZHANG, L., LU, Y., SUN, J., ZHOU, X. \& TANG, B. 2015a. Subthreshold vagal stimulation suppresses ventricular arrhythmia and inflammatory response in a canine model of acute cardiac ischemia and reperfusion. Experimental physiology, 101, 41-49. 
ZHANG, L., LU, Y., SUN, J., ZHOU, X. \& TANG, B. 2016. Subthreshold vagal stimulation suppresses ventricular arrhythmia and inflammatory response in a canine model of acute cardiac ischaemia and reperfusion. Experimental physiology, 101, 41-49.

ZHANG, Y., CHEN, A., SONG, L., LI, M., HE, B. \& CHEN, Y. 2015b. Vagal nerve stimulation reverses cardiac dysfunction and subcellular calcium handling in heart failure rats after myocardial infarction. Journal of the American College of Cardiology, 66, C35.

ZHANG, Y., ILSAR, I., SABBAH, H. N., BEN DAVID, T. \& MAZGALEV, T. N. 2009a. Relationship between right cervical vagus nerve stimulation and atrial fibrillation inducibility: therapeutic intensities do not increase arrhythmogenesis. Heart Rhythm : the official journal of the Heart Rhythm Society, 6, 244-250.

ZHANG, Y., MOWREY, K. A., ZHUANG, S., WALLICK, D. W., POPOVIĆ, Z. B. \& MAZGALEV, T. N. 2002. Optimal ventricular rate slowing during atrial fibrillation by feedback AV nodal-selective vagal stimulation. American Journal of Physiology. Heart and Circulatory Physiology., 282, H1102-1110.

ZHANG, Y., POPOVIC, Z. B., BIBEVSKI, S., FAKHRY, I., SICA, D., VAN WAGONER, D. R. \& MAZGALEV, T. N. 2009b. Chronic vagus nerve stimulation improves autonomic control and attenuates systemic inflammation and heart failure progression in a canine high-rate pacing model. Circulation Heart Failure, 2, 692-699.

ZHENG, C., LI, M., INAGAKI, M., KAWADA, T., SUNAGAWA, K. \& SUGIMACHI, M. 2005. Vagal stimulation markedly suppresses arrhythmias in conscious rats with chronic heart failure after myocardial infarction. Annual International Conference of the IEEE Engineering in Medicine and Biology Society, 7, 7072-7075.

ZHOU, X., ZHOU, L., WANG, S., YU, L., WANG, Z., HUANG, B., CHEN, M., WAN, J. U. N. \& JIANG, H. 2016. The use of noninvasive vagal nerve stimulation to inhibit sympathetically induced sinus node acceleration: a potential therapeutic approach for inappropriate sinus tachycardia. Journal of Cardiovascular Electrophysiology, 27, 217-223.

ZIEGLER, D., SUZUKI, T. \& TAKEUCHI, S. 2006. Fabrication of flexible neural probes with built-in microfluidic channels by thermal bonding of parylene. Journal of Microelectromechanical Systems, $15,1477-1482$.

ZIOMBER, A., JUSZCZAK, K., KASZUBA-ZWOINSKA, J., MACHOWSKA, A., ZARASKA, K., GIL, K. \& THOR, P. 2009. Magnetically induced vagus nerve stimulation and feeding behavior in rats. Journal of physiology and pharmacology : an official journal of the Polish Physiological Society, 60, 71-77.

ZITNIK, R. J. 2011. Treatment of chronic inflammatory diseases with implantable medical devices. Annals of the Rheumatic Diseases, 70, i67-70.

ZUANETTI, G., DE FERRARI, G. M., PRIORI, S. G. \& SCHWARTZ, P. J. 1987. Protective effect of vagal stimulation on reperfusion arrhythmias in cats. Circulation research, 61, 429-435. 